\title{
The Net Generation's Stories: A Typology
}

Even though the research interests in the study "Communicative Publics in Cyberspace" focused on the courses of action ${ }^{1}$ which developed and were described by the network actors and bloggers in virtual space, the impression soon emerged that, in combination with the themes, feelings, and biographical details they reported on, the depicted actions and practices were being used to tell stories. A secondary analysis of the interviews and visualizations zoomed in on these narrations, which illuminate further facets of the everyday reality of adolescents and young adults in the age of the Internet. Out of the 33 interviews we conducted, 21 were selected with network actors and bloggers from 11 countries (Austria, Germany, Italy, Switzerland, Turkey, Ukraine; USA; Bahrain, Saudi Arabia, United Arab Emirates, Yemen $)^{2}$ in which there was a clear narrative focus which could be characterized as one of several types of narrations. Hints as to which interviews to include in the secondary analysis were provided by the core categories used to identify the actions and practices under investigation. ${ }^{3}$ It is not at all surprising that these courses of action

\footnotetext{
${ }^{1}$ The actions and practices which were identified and the subject constructions which were embedded in them were analysed by Christina Schachtner and Nicole Duller in "The Internet as a Place of Communication: Digital Practices and Subjectification" (2014).

${ }^{2}$ The network actors and bloggers from the Arab world and the USA were interviewed in English. The other interviews were carried out in German; any quotations from these interviews have been translated into English.

${ }^{3}$ More information about the methodology and research methods can be found in the introduction to this book.

(C) The Author(s) 2020

C. Schachtner, The Narrative Subject, https://doi.org/10.1007/978-3-030-51189-0_4
} 
provided the hints as they were essential components of the particular narration.

Most of the interviews had one dominant narration; if they included a clear focus on a second type, we also analysed that but did not include those narrations which were only hinted at or fragmentary. The existence of dominant narrations points to the irreducible, mentioned in Sect. 2.3, which is unique to every individual and which arises from subjects grappling with the difference between the stock of ideas, plans, likes, and dislikes which has evolved from their life histories and the current expectations imposed on them by society. This confrontation leaves its mark on the subject's handwriting, metaphorically speaking, which then runs as a common thread through their narrations and which can be identified as a dominant element. A comparison with examples from music and art should make this even clearer. Why can we easily identify works by Johann Sebastian Bach, Philip Glass, Paul Klee, or Claes Oldenburg? Because they bear the idiosyncratic signatures of their creators in a particular sequence of notes or in a particular combination of colours and shapes.

Our interviewees did not deliberately set out to tell a story; they were just describing their experiences, talking about what they do, witness, and feel as network actors and bloggers. They were presenting pieces of a narrative jigsaw puzzle, some of which they put in a logical order and some of which they did not, some of which pointed to the beginning of a narration and some of which did not, some of which had an ending and some of which - considerably more in fact—had an open end. The narration arises out of the sum of the jigsaw pieces and the specific links between them; it is implicitly present and the protagonists are not necessarily aware of it. It spins the "subterranean web," as it were, which the individual remarks stem from and which endows them with meaning. The focus of the analysis is the act of telling stories about what and how things are communicated in virtual space and not telling stories in virtual space, as would be the case when analysing blogs or computer games, for example. It is possible to distinguish between two levels of storytelling: (1) the level of the narrative acts which are developed in the internet and (2) the narrations about these acts, which is what this book is about. The narrations presented here are very often intertwined with virtual space but they also go beyond that, referring to other, current aspects of life and earlier phases of life alike. These are narrations in the age of the internet in the sense that media technology plays a self-evident and indispensable role in them. 
First of all, all passages with narrative content in the interviews were extracted as they came. Then the individual passages were placed in thematic clusters, resulting in the following list of questions in accordance with which the statements in an interview could be classified:

- What are the characteristic attributes of the narration? (attributive level)

- What actions stand out? (actional level)

- What motives/goals can be identified? (motivational level)

- What feelings are associated with the motives/goals and actions? (emotional level)

- What reflections are revealed? (reflexive level)

- What role do digital media play in the narration? (media level)

- What external consequences/reactions are revealed in the narration? (consequential level)

- In which sociocultural context is the narration embedded? (contextual level $)^{4}$

After the interviews had been analysed individually, they were compared to each other, firstly to identify overlapping characteristics which would justify assigning individual interviews to particular types and secondly to identify differences between the interviews assigned to a particular type, indicating variations on that type. The following six types could be identified in the empirical data: narrations about interconnectedness, self-staging, supplying and selling, managing boundaries, and transformation as well as setting out and breaking away. The account of the individual types and subtypes of narrations follows the questions given earlier, albeit without referring to them explicitly in the text. In this way, the pieces of the narrative jigsaw puzzle are structured, but not in a temporal order; instead they are structured along the various dimensions of the narration. This structure is governed by our interpretation and not by the structure of the narrator's tale. The narrations are illustrated with the help of quotations from the interviews; when one and the same quotation is required to illustrate individual thoughts under different headings in different sections, it is simply repeated. The verbal presentations are

\footnotetext{
${ }^{4}$ The list of questions which we used to create the thematic clusters of narrative elements signals a very broad conceptualization of narration which includes justifications, reflections, and explanations alongside descriptions of a storyline.
} 
complemented by selected visualizations which were produced by the narrators, providing a more in-depth insight into the particular type of narration.

\subsection{Narrations About Interconnectedness}

A common thread running through the narrations about interconnectedness identified in the interviews is an orientation towards the outside world, a communicative connection to other network actors. The narrations in this category differ according to the extent of that interconnectedness and the type of connection.

\subsubsection{Showing and Exchanging}

The narrations about interconnectedness follow the central theme of "showing and exchanging" in which network actors cross local and regional geographical borders in the internet on a communicative basis; communication with the rest of the world takes centre stage. It is not so much a question of sharing personal matters with anybody who is interested but rather of showing them one's own country, one's own culture. At the same time, there is an interest in exchanging views on events and social developments in other parts of the world. Narrations involving interconnectedness of this type were only identified in interviews with the Arab network actors.

Two 26-year-old male network actors from Saudi Arabia told us that they both run blogs addressed at people living in the Middle East but also in the rest of the world. They blog about social topics, technology, and art through texts and images. One of the two runs a photography blog in which he presents political photo projects which deal with fear, violence, and refugee issues and on which he cooperates with artists worldwide. The second network actor, who mostly talked about his verbal interconnectedness, recounted how he discusses political events all over the world with his friends in America. Both of them spend a lot of time creating their communicative offerings, constantly uploading things from their mobile devices. Their posts trigger many welcome reactions, including comments, questions, and many followers. One of the bloggers also talked about undesirable ones, including the authorities regularly accessing his blog. This particular blogger had also been arrested several times when taking 
photos for his blog in public, on the insistence of passers-by, mind you, and not of the police.

Both of the network actors agree that they want to put a different complexion on Saudi Arabia to the one the world is normally presented with by the official media, as the following statements document: "I'm trying to allow people to look into things especially in Saudi Arabia and especially when they look back to Saudi Arabia through my blog to see the social and intellectual fabric of what makes Saudi Arabia Saudi Arabia." The second network actor explained: "I use it [the internet] as a way to show kind of the Middle East and Saudi Arabia specifically from the ground, from a perspective that's not really represented in the news." The picture drawn by one of the two network actors (Fig. 4.1) shows him ready to receive and transmit: What he needs for global exchange is a head, complete with a brain and antennae, surrounded by sound waves which get to him, ears which can hear, and a mouth which can talk.

Transnational interconnectedness is accompanied by feelings which either arise as a reaction to messages which are received or are features of the network actor's own messages. He admitted that he is proud when other network actors ask him questions as an expert but also when he can show his feelings: "Whenever an emotion comes in I actually share it proudly and I say, 'This is what I'm feeling right now.' I'm not ashamed of it."

Reflexive elements in narrations about interconnectedness of this type are revealed in connection with self-representations. Whereas communication with the rest of the world is a part of his self-representation which the network actor who has already lived in various countries takes for grantedhe calls himself a "citizen of the world"-for the second network actor it leads to a split into an offline and an online representation of the Self, or into a local and a global representation of the Self. He explains that "in real

Fig. 4.1 Ready to receive and transmit (network actor, m, 26, Saudi Arabia)

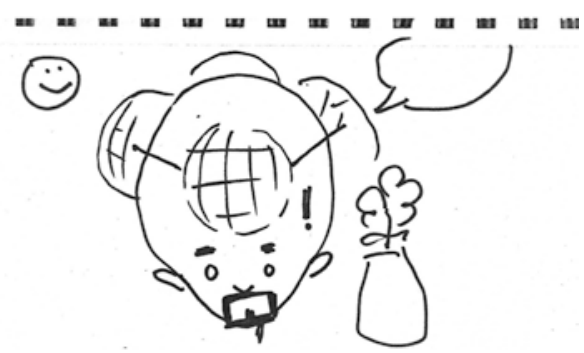


life I'm a Saudi guy living in Saudi Arabia ... but online I'm multinational, I'm multigeographical."

Both network actors value digital media in their attempts to interconnect. For one of them, they are places "where interaction between Saudi Arabians and international community started to happen." They both appreciate the potential for sharing their posts but also the potential for solidarity from online communities, which one of the network actors experienced when he was having problems with the authorities. As he put it, "[ $\mathrm{t}]$ here was a community that was supporting me."

The narrations about interconnectedness outlined earlier are embedded in biographies in which encounters with other cultures have an important role to play. One of the network actors has parents who come from different countries; the other has lived in various countries and on various continents so far in his life. These biographical experiences may have awakened their interest in and curiosity towards the Foreign and, at the same time, nurtured their skills in transnational communication. For both of them, their interest in the Foreign corresponds to their appreciation of the Own which the attention of Others should be drawn to.

\subsubsection{Seeing and Being Seen}

The motto of "seeing and being seen" is best illustrated by a story about interconnectedness told by a 29 -year-old network actor who lives in Vienna. In this narration, too, outward-looking orientation and being connected with Others are in the foreground, but the radius of his connections is much smaller than in the interconnectedness narrations with the central theme of "showing and exchanging"; it encompasses, essentially, the places where he has lived so far in real life, all of which are in the same country. His communicative contacts are not political in nature but rather personal. This story about interconnectedness has another special feature, namely that the opportunities for digital interconnectedness do not only connect people but can also be directed against Others.

The starting point for the 29-year-old's narration about interconnectedness was a profile picture which he posted online. He described how "it simply got bigger and bigger and then I actually almost didn't realize that I was becoming so engrossed in it." Thanks to his internet presence, he came into contact with old friends again, whether he contacted them or the other way round. The 29-year-old does not cultivate his online friendships via a blog but via his own profile, with text and images, and by 
chatting, sometimes all night long. In the first few weeks, when he started to "become so engrossed" in the internet, he concentrated on looking for contacts, gradually building up a network of friends. But soon he started to rank them, with family members and close friends right at the top, "followed by ... second-class, third-class, fourth-class friends, and then my acquaintances come somewhere after that."

The original motivation behind his online activities, he claimed, was so that he could find old friends with the help of the internet, but he was also attracted by the thought that Others would be able to find him, as well as by the possibility of wielding power by controlling information flows. "You really are like a, a, a god in this respect" was the way he put it. The 29-year-old wants to see things, to see how other people live, even when the Other happens to have cut himself or herself off from him. He recounted how he continued to monitor the mailbox of an ex-girlfriend after they had split up because he knew the password. But he also wants to be seen himself, something he called "balm for the soul." Those who stop paying him attention risk being "kicked off" his network of friends but should certainly be aware of it: "They should by all means know that they've been kicked off my list of friends so that they're annoyed about it." This is a clear indication of the feelings on the part of the network actor as well. He, himself, thinks that he is pretty "cool" when he "throws people off" but in fact his aggressive stance cannot be overlooked.

In this story about interconnectedness, reflexive elements take up much space. The network actor critically challenges his own behaviour: "What am I actually getting up to? I perch here permanently, staring at the 'stupid screen' and waiting for somebody to deign to let me be part of their lives." Being connected with Others has turned into a drug for him, fed by the fear that he could be "left out," that is no longer belong, be alone, be lonely. This fear could possibly explain why he illicitly clings onto friends who have cut themselves off from him. Even he is aware of how dubious this is; he called it "stalking," adding "that's really, that is, that's just like the Stasi, it's completely crazy."

It is not digital media per se which facilitate interconnectedness for this network actor, in keeping with the motto "seeing and being seen"; his medium of choice is Facebook. "Facebook, it's like a bulletin board" on which a slip of paper can be posted, figuratively speaking, with the message

\footnotetext{
${ }^{5}$ The colloquial term for the Ministry of State Security in the former GDR, one of the functions of which was to keep the population under surveillance.
} 
"Hey! I want to see you!" Facebook is like "a big room where everybody is standing around and you can decide, am I going to listen to him, or am I going to listen in there?" Facebook appears to be such an attractive platform for him because there is plenty of room for manoeuvre when looking for new contacts, both for him and the Others. He dismisses the idea of using a mobile phone for such purposes because it is too direct a way of getting into contact with Others, one possible consequence of which, as he pointed out, could be being turned down directly as well.

In contrast to the interconnectedness narrations about "showing and exchanging," particular shared sociopolitical topics are not important for this 29-year-old; instead interconnectedness itself is the reward. For him it is about social connections, about feeling good as part of a greater whole, which is frequently underlined by the words he uses like "becoming engrossed" and "being in the thick of things."

\subsubsection{Sharing}

The interview with a 21-year-old American student serves as an excellent example for this type of interconnectedness; in no other interview was the word "sharing" used so conspicuously often. In a similar fashion to the previous interconnectedness narration "seeing and being seen," this interconnectedness narration is characterized by a strong outward orientation, by the wish to be connected, and by nodes which are made up of people the network actor knows from his immediate social context. Staying in touch with his family and friends is particularly important for the 21-yearold, and what is most important about staying in touch with Others is the sharing of observations, experiences, impressions while travelling, and, above all, photos. This theme of staying in touch distinguishes this narration from the interconnectedness narration "seeing and being seen," where it is a question of being connected per se, and reveals some similarities with the interconnectedness narrations "showing and exchanging," although there the themes are sociopolitical in nature whereas here the "sharing" concerns private matters.

The 21-year-old's interconnectedness narration began with the platform MySpace, where he swapped music with Others. When most of his friends changed over to Facebook, he, too, changed to that platform. Now, he explained, he is digitally networked on a permanent basis, both via email and the social media: 
For emails I'll stay on all days. I check in multiple times throughout the day. Facebook I'll check it once briefly in the morning. ... I'll check it maybe around lunch time and then at the end of my day.

He posted photos for his father on the platform, where he had set up a photo album, to give him an impression of his life at university but kept in touch with his mother by calling her regularly as she was not so internet savvy.

The 21-year-old gave two reasons for his digital sharing habits: On the one hand it was good for the family, and on the other they allowed him to stay in touch with people he grew up with:

I want to maintain connections to people. I wanna know where people arrive within their lives, so when I go back to New York like I can still, you know, be a part of their life and they can be a part of mine and you kind of keep your friends.

Moving away from New York to study elsewhere in the USA should not cause friendships to come to an end. Face-to-face contacts can be kept up digitally for the time being and then turned back into face-to-face contacts.

Unlike the protagonists in the interconnectedness stories about "showing and exchanging" where friendships are often limited to the internet, this network actor assumes that friendships must arise offline and, at best, can be continued online. Far away from his home town, he regards Facebook as a vital stage on which to share his life with Others. The multimediality of the medium allows him to use images both to document his life and to keep in contact.

This interconnectedness narration is associated with the domestic situation in which members of a family live in completely different places, whether due to divorce or educational mobility. In this case, studying elsewhere meant that the network actor had to leave his home town of New York and all of his friends there. Sharing acts as an integrative mechanism to maintain networks within the family and between friends; digital media are the prerequisites for allowing such a mechanism to evolve. 


\subsection{Self-Staging Narrations}

In the narrations about self-staging, the focus on the I is much more obvious than in all of the other narrations, or, to be more precise, the focus is on the presentation of the I for an audience (Seel, 2001, p. 49). The Others are not interesting as unique individuals but merely as spectators and commentators. The I is quite deliberately set centre stage, the staging being carefully prepared. Issues of revealing and concealing are paramount. Stories about self-staging were recounted exclusively in interviews with European network actors and bloggers.

\subsubsection{The Adored Star}

The network actor introduced in the interconnectedness narration "seeing and being seen" also told a self-staging story. In the second narration, this showing-oneself-off as opposed to an interest in Others is pushed to the fore in the expectation of being admired by the digital audience.

The 29-year-old talked about his attempts at self-staging in connection with stays in hospital. "Whenever I do something to myself, I post the $\mathrm{x}$-ray online," he reported. When he was in hospital for a knee operation, he represented himself with a knee "where everything was hanging out of it." With this series of self-staging posts he wanted to show "what a tough cookie $^{6}$ I am [laughing] and what I've survived so far." If Facebook didn't exist anymore, he replied in response to the researcher's question, it would be "a veritable disaster ... because I also enjoy showing myself off." $\mathrm{He}$ went on to explain how he presented two versions of himself online: "an ideal version," without the "lumps and bumps," with which he wanted to create the impression that "wow, he's an absolute super cool guy; he's never experienced failure in his life," and a second version, "which includes the stupid photos as well," which was for his family's eyes only. Both of the presentations are carefully thought out in order to create a specific impression: "I'm very choosey about what information I pass on so that I create this or that impression of myself." His drawing here tells the story of the "super cool guy" (Fig. 4.2). He's the show-stopper in the picture, straddling a pile of status symbols like a laptop, car, and basketball, his skis hanging around his neck to demonstrate how athletic he is, looking at himself in a mirror, out of which his own reflection is looking back at him,

\footnotetext{
${ }^{6}$ In German, he said "Was für ein harter Knochen," a pun involving "hard bones."
} 


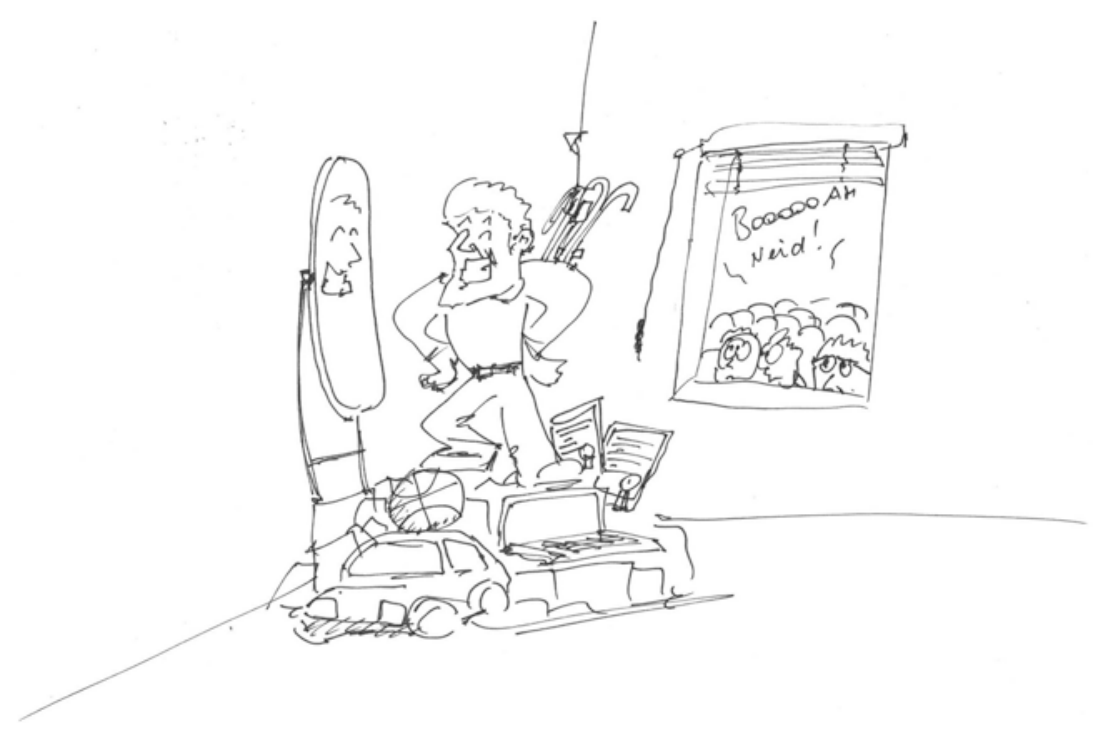

Fig. 4.2 The absolute super cool guy (network actor, m, 29, Austria)

just like Narcissus, who saw his own image in a pool and fell in love with it. His audience is looking up to him through the window behind him in admiration and envy. Being allowed to admire him should be considered an honour in his mind: "Some are allowed to or are able to look in. Others are standing at the back. They can't see anything at all." As a finishing touch, he added a blind to the window, enabling him to escape from view by closing it if he so desires. In this drawing, the game of revealing and concealing is presented as a kind of power game.

Alongside feelings of power, this self-staging narration also includes pride at the network actor's own attempts at staging himself, which he repeatedly describes as "cool." When telling this story, he always includes a touch of irony, as though he wants to distance himself from his narration, as though he knows about the discrepancy between his staged version of himself and reality.

The virtual space which he has set up for himself on Facebook is described as "a small living room," which indicates that he feels at home there and can act out his aspirations. At the same time, it is important for him that he can open up this living room to make himself visible to Others, not just to his friends but to the whole wide world, as he explicitly stresses. 
Facilitated by the transnational character of social media, this global visibility attaches unprecedented importance to the self-staging of an individual.

\subsubsection{Role Model and Seeker in One}

In this self-staging narration told by a 23 -year-old male network actor, the focus is also on the I and especially on the desire to be a role model for Others. At the same time, this I is also a seeking I, which needs commentators as well, and not just an audience in the manner of "the adored star." It is an I en route to a better, open future.

The self-staging narration of the 23-year-old blogger (see also "Time and Narrative" in Sect. 2.1.1.2), who was born and still lives in a large European city, began in 2009, when he set up his own blog. ${ }^{7} \mathrm{He}$ explained that he chose English as the language of his blog because it is an international language which he spoke better than his mother tongue. In his first article, the graduate of fashion design presented his own fashion collection named "the dramatic human perfectionist." He continued to write articles on fashion, often after he had been to fashion shows and press conferences. He also described how he wrote articles about the meaning of life. His second phase of blogging started with an article which he wrote after splitting up with his boyfriend in which he, together with his readers, attempted to figure out

[w] hether it [love] is something social, whether it's a chemical process, or whether it really is something that Walt Disney impressed on us in our childhood which we actually ... through those classics like Sleeping Beauty, Snow White, and Beanty and the Beast which we actually were taught to believe that it really exists, that you stay with the same person for ever.

He was inspired to write this kind of blog, in which aesthetic issues relating to fashion intermingle with questions about the meaning of life,

${ }^{7}$ The name of the blog is not given for reasons of anonymity. 
by the teen series Gossip Girl and the TV serial Sex and the City. ${ }^{8} \mathrm{He}$ related how he spent eight to nine hours writing each article and wrote three to seven articles a week. At the time of the interview (2011), he had 5000 readers who posted both favourable and critical comments.

The motivation behind writing his blog was that he wanted to give expression to his personality, in a way which he was responsible for shaping himself: "I believe that it is important that you try to influence this image [that you present to the world]; that you push this image in the right direction." He wants to be seen as "somebody who has an idea of fashion, where you notice that he has a degree ... that he busies himself with life but that he doesn't stop fighting either and also lives his dreams." The 23-year-old comes across as somebody who is very competent but at the same time he admits that he faces problems and setbacks which he has to overcome. This is where he slips into his role as a role model, something which is even more obvious at another point in the interview when he explained that

[i]t is important for me to give a little of myself, or to kinda show people that life goes on after splitting up ... that it's a question of continuing to live your life and to enjoy life anyhow, even when it's a struggle and hard work.

Feelings play an important role for the 23-year-old when blogging; he describes them as being the catalyst for his writing: "My blogs are fundamentally driven by my emotions. So that I really start writing when I am really very sad, or very happy, or in the middle of an identity crisis." $\mathrm{He}$ writes about his feelings in order to express his own personality and to engage emotionally with his readers: "I believe that it is very important that people have this emotional bond with a blogger."

The 23-year-old provides a series of reflexive references to his blog. When asked why negative comments are also important for him, he

\footnotetext{
${ }^{8}$ Gossip Girl is a series targeted at teenagers which ran on the US network The CW from 2007 to 2012 . The sixth season was broadcast in German-speaking countries in 2013. It is about topics like friendship, love, and drugs in a group of privileged upper-class adolescents growing up in New York City's Upper East Side reported on by the blogger Gossip Girl (Wikipedia, 2020).

${ }^{9}$ Sex and the City is a US TV series which was filmed between 1998 and 2004 and ran for six seasons. The focus is on four women from New York and their erotic and sexual experiences as well as their thoughts on human relationships in general. The series is based on the novel of the same name by Candace Bushnell.
} 
responded: "Because you can't evolve ... when you only ever get positive reviews." This comment reveals him to be a seeker. He talked about blogging having turned into work for him, that it was no longer possible to separate his work from his private life, and that for 24 hours a day. As he said, "[i]n principle, I work on my blog 24/7."

The digital media provide this blogger with a platform for his selfstaging in the form of a blog: "It's like ... having cameras pointed at you and you're filming an episode in your own, personal series." At the same time, they create the housing for his quest for the Self which he wants to promote in exchange with Others. Whereas the adored star portrays himself as having already reached his goal, the 23-year-old blogger is still on his way.

It is childhood experiences, amongst others, that form the background for this self-staging story. In his family, it had always been important to put across "a good social image as a family." His interest in fashion, which had become one of the two main content areas of his blog, was strongly influenced by his grandmother, whom he characterized as a "grande dame" who "always took very meticulous care about the way she presented herself." This was amplified by a magazine, namely Vogue, which, when he saw it for the first time at the age of nine, gave him the feeling that "Yes, this is it, this is what I want to do one day." For him, fashion was also attractive because it promised "a better future." This promise could be the motivation behind the recurrent theme in the 23-year-old's blog of being on a quest. A second time, many years later, media provided a guideline for the blogger once again; this time it was the two US TV series mentioned earlier which caused him to write his blog in a "mixture of comedy and drama." Just like in the self-staging narration "the adored star," this reference to "comedy" brings humour into play; in the self-staging of the 23-year-old, it may well be not so much with the intention of distancing himself from his own self-staging but in order to stave off the "drama" which he senses in his own life, to turn the "difficult into the easy" (Bönsch-Kauke, 2005, p. 17). ${ }^{10}$

\subsubsection{The Counter-Model}

The I that is presented in this type of self-staging narration is not an I which already exists which needs to be adored or reviewed by others; it is

\footnotetext{
${ }^{10}$ All quotations from German publications were translated into English for this book.
} 
an I which does not (yet) correspond to the real I in the eyes of his or her creator and on which certain desires are focused. The desired I is fixated on certain concepts of beauty or desired patterns of behaviour. The individuals concerned think very carefully about which characteristics the desired I should have and work very carefully on their ideal image. The "counter-model" type of self-staging narration was identified in three interviews with young female bloggers between 21 and 24 years of age.

The self-staging narration of the 21 -year-old was already evident in the choice of her blog nickname, namely Gaia, called after the main character in the series of novels Fearless (see also "Self-Knowledge and SelfUnderstanding" in Sect. 2.2.1.2). She recounted how she read the books when she was 12 and even then considered Gaia to be a role model as she was not afraid of anything, having no "fear gene." The 24-year-old was also inspired by a media figure for her choice of nickname. On her blog she calls herself Asu, borrowed from the manga character ${ }^{11}$ Asuka, a "cheeky redhead." Asuka appears to embody something desirable for the blogger because after describing her character she said: "So it's not surprising that I called myself after her." However, she not only calls herself after her; in the pictures on her blog, she also models her appearance on Asuka, wearing "girly clothes which are very pink and very sparkly." The third blogger ( 22 years old) uses photos as part of her self-staging as well, presenting herself in such a way that "people are often surprised that I look completely different in real life." She wants to appear "interesting, maybe a little bit mysterious." What the three bloggers have in common is that they wish to present a favourable image of themselves online. The 22-year-old referred to her ability to "work [well] with perspective, holding my head in such a way that my face looks more or less ok" whereas the 21-year-old recounted how she coerces her boyfriend into "photographing me a thousand times until I'm happy with what I look like on the photos."

All three young women estimated that they dedicate a great deal of time to their online presence: one to two hours for the 21-year-old, two to three hours working on a blog entry for the 24-year-old, and three to four hours online daily and even longer at the weekend for the 22-year-old.

\footnotetext{
${ }^{11}$ Manga is a term used in Japanese to refer to comics and cartoons. Manga figures are based on a schema of childlike characteristics; their big eyes and cupid lips stand out in particular.
} 
The three bloggers have set up their self-staging for an audience as one way of "fishing" for comments. Compliments are like "balm for the soul" according to one of them whereas another admitted that she was grateful for compliments. But there were also ambivalent-to-negative reactions from their readers. The blogger who went by the name of fearless Gaia had to deal with the following comment one day: "On your blog you are completely different than in real life ... in reality you appear to be a bit shy." Another of them was happy about all comments, even the negative ones, as long as they were "nicely formulated" and included "constructive criticism."

The motivation behind this kind of self-staging is partly indirect and partly direct. The remarks made by the blogger nicknamed Gaia indirectly reveal her desire to take on Gaia's characteristics by adopting her name. She had already started doing so: Gaia's mastery of all forms of martial arts had motivated her to take up one in real life. She found that the fearlessness which she so admired had a general effect on her behaviour: "It's no longer important at all what other people actually think of me, not even in real life."

The other two bloggers formulated their motivation more directly. One of them said that she used her own staging to "persuade" herself that "I look wonderful and everybody else believes that as well" and the other one explained that she wanted to take centre stage, "which I don't do so often in real life." In addition, she found it positive when she could decide for herself "how somebody sees it [her as an individual] or how somebody perceives it [her]." The possibility of influencing the perception of Others gave her a feeling of power, she claimed.

From an emotional perspective, not all of them managed to sustain their intention to exploit this type of self-staging as a counter-model. Only one of the three bloggers focused on the communication of positive feelings corresponding to her ideal image; the other two also talked about what stressed or bothered them in real life, even if that contradicted the "lovely image" of themselves which they had created. One of them used a blog entry to describe how she felt at her little brother's funeral; the other wrote entries when she was "very lovesick or was really cheesed off." She assigned these feelings a positive turn in her narrative, however, explaining that such emotional states gave her "an awful lot of energy" and that she drew her best pictures in that frame of mind. Happiness and/or anger are not only part of these two bloggers' self-staging; they are also felt in response to the reactions which come from outside, depending on whether 
they read "you're just a superficial, silly cow" or "I like the colour of your eyes."

As self-staging is a deliberate process, it is not at all surprising when the three narrators relate to this process reflexively, reflection being a prerequisite for an individual being aware of their own behaviour. All three narrators integrate not only their own actions in their reflexive considerations but also those of Others, namely the readers of their blogs. One of them admitted that she only blogged to elicit responses, calling herself "addicted" to this feedback. Another one explained how she enjoyed "creating some kind of illusion," in relation to her appearance and particularly for Others, although maybe for herself too. Using the term illusion certainly points to her knowledge of the discrepancy between staging and reality. The third blogger associates her self-staging with a desire to overcome the feeling that "I'm a nobody and I can't do anything either." Admittedly even she sees a discrepancy between the girl in make-up in her online version of herself and her interest in computer games, programming, and numerical codes, none of which is visible in her self-staging.

Without the technical possibilities of digital media, the types of selfstaging portrayed here would be inconceivable. Their multimediality and interactivity provide the prerequisites for the construction of an I that represents the longed-for Other. Above and beyond that, their network structure allows an audience to gather which should comment on the attempts at Self-construction.

The examples of self-staging as a counter-model do not come about by chance: They are related to biographical experiences, some of which the bloggers referred to themselves. The attempts to create an illusion with the help of self-staging which were mentioned earlier are related to different experiences. For one blogger it is the fact that her own body measurements are not ideal, as she admitted: "I weigh-I don't know-twenty kilos too much or twenty kilos too much in the eyes of most people." For the second blogger, it is her height of $1.44 \mathrm{~m}$ which prompts others to ask questions which she considers personal attacks and which she tries to fend off through her self-staging by disclosing her height and scoring highly with her sparkly self-image, amongst other things. This representation of the Self also helps her to counteract the feeling that "I'm a nobody and I can't do anything either," which is connected with her situation as a migrant. Due to her different cultural background and poor language skills, she explained how she became an outsider at school in the country she moved to, attempting to turn the situation around by teaching herself 
to be more self-confident. Her self-staging online is possibly part of this training where she feels she is in a better position than she is offline because then she is the one who is in charge and who can delete unwelcome reactions. The third blogger, who chose the nickname Gaia, also had to overcome a radical change in her life. When she started studying, she had to move away from the rural community where she had spent a "happy childhood" to a city in another region. Her identification with fearless Gaia could be a strategy to steel herself against the challenges and risks of bigcity life.

\subsection{Stories About Supplying and Selling}

Staging is also involved in the narrations about supplying and selling; not the individual but rather material or immaterial products are at the centre of attention here. Aided by the resources of digital technology, network actors carefully present, evaluate, endorse, and comment on these products, frequently on behalf of a company. Sometimes they produce or invent the products themselves, especially in participatory projects where they want other people to join in. Promoting and praising a product involves material or immaterial gain, for example being given the product, receiving a fee, or having others admire a home-made product. The addressees of the product endorsement play an important role; it is about anticipating or stimulating their interest in words and images. The digital suppliers and sellers differ depending on whether they are presenting products to buy or projects which others can take part in, although there is no clear-cut distinction.

\subsubsection{Objects and Designer Products on Offer}

One of our interviewees, who was 14 years old at the time, endorsed torches, smart phones, and dental bleaching kits, amongst others, on his blog. Companies contacted him via a particular home page and sent him products to test. He presented them in the form of personal testimonials, which took him a long time to produce: "When I write something about the torches, it can take me a whole day ... to do so." He recounted how he reread his articles several times, never losing sight of his potential readers. "It just takes one sentence to put somebody off," he explained, "you have to be really careful what you write." He continued that he wanted to be successful and his definition of success was to persuade many readers or 
potential buyers to take note of his testimonials. This was also the goal of a 24-year-old network actor, who sees himself as a candy seller in his endorsement of designer products, as depicted in Fig. 4.3.

This network actor has located himself and his kiosk on the side of a motorway, which symbolizes digital flows of communication for him, and he is trying to advertise his products like sweets. Their sugary taste should tempt people to stop. He has even provided a car park for them, to the right of his kiosk. The 24-year-old is the seller, although he pointed out that several friends were also involved in the production of his blog, either as programmers or photographers. He described the joint preparation of the designer products and their presentation on his blog as a commercial enterprise.

Touting for readers is something both bloggers have in common, as they explicitly stressed. They have to be capable of anticipating needs, developing empathy, and managing their internet presence to suit their readers. When I looked at them, it stood out that both blogs present their

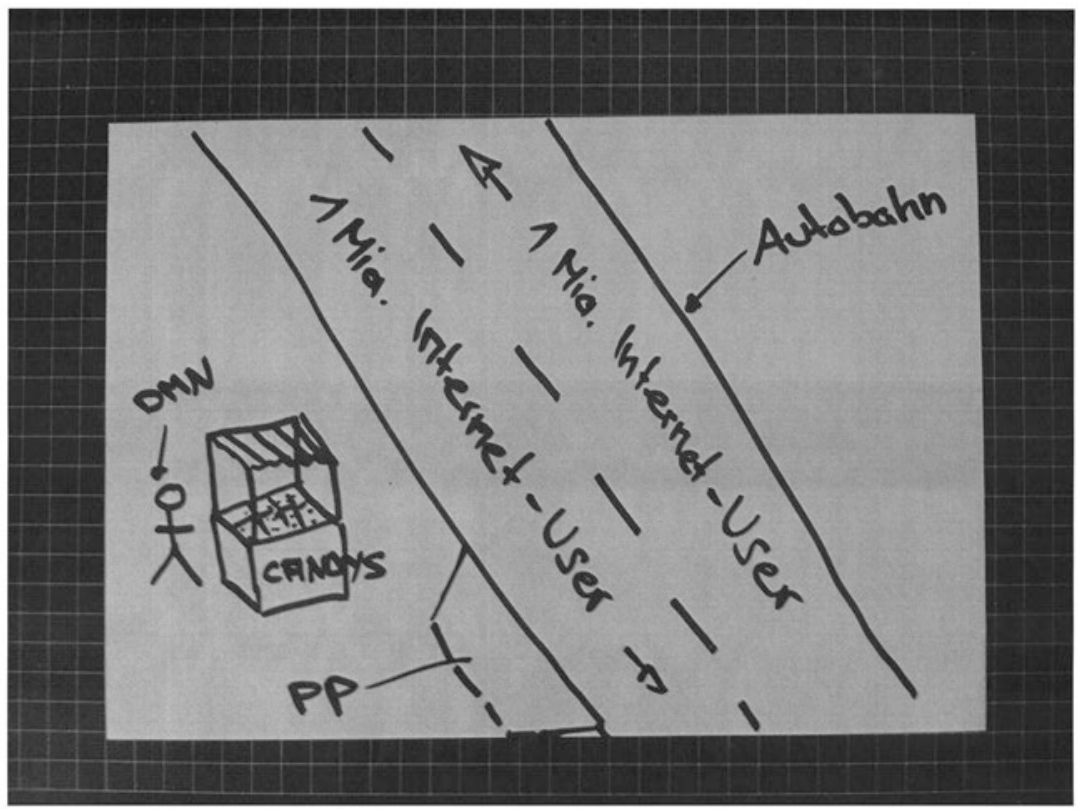

Fig. 4.3 The blogger as a candy seller (blogger, m, 24, Switzerland) 
wares embedded in a series of entries which are about completely different topics. These include reports on the bloggers' everyday lives, their relationships with other people and with animals, their illnesses, very personal topics in fact. It could be the combination of business activities and private life which is somewhat irritating at first glance because it is completely different to professional advertising. Nonetheless it increases the blogs' appeal, thus ensuring that the products attract the desired attention.

What motivates both network actors to post their testimonials online? The 24-year-old hopes that he will get commissions in the design sector whereas the 14-year-old reckons that he can keep the products he is sent and might even be paid a fee, depending on how many people read his blog. Both of them are interested in a large number of readers for financial reasons, but that is not the only motivation behind writing their blogs.

The 14-year-old describes how his readers' comments "helped him get on." As the comments relate to both his testimonials and entries about his personal life, which he called diary entries, it can be assumed that this "helping him get on" refers to both aspects. The following passage from the interview would support this assumption. The 14-year-old explained: "The blog is actually my diary. When something happens that I find important, I write it down in my blog too. You hide a diary, more or less, and a blog is public, of course." When asked why he preferred to write about his life in public, he replied: "Because more people can read it, and yes, they can respond to it." In this way, his own life becomes a product to present which attracts public feedback.

Emotion-wise, the digital suppliers and sellers appear to be less involved than the protagonists in the interconnectedness and self-staging narrations; yet they too talk about feelings like pleasure and pride over compliments for their product presentations or the way in which they live their lives.

Thinking about the roles of the readers of their blogs could be interpreted as a reflexive act; otherwise their attempts to exploit private blogs for their own mini businesses are not called into question. This could be taken as proof that the logic of profit, albeit outside official channels, has become a matter of course for the bloggers which leaves its mark on their thinking and acting. Digital spaces are used as salesrooms in which the products on offer can be staged with the help of multimedia tools and which guarantee a high distribution potential thanks to their transnational character. 
As far as the autobiographical integration of the narrations about suppliers and sellers is concerned, conjectures are only possible in relation to one of the two network actors. The configuration of his blog as a shop window with a colourful display of products reflects his personal life situation, which is marked by a chronic illness which has excluded him time and again from his habitual everyday contexts. It seems as though setting up his blog as a shop window allows him to build up his own new universe. On a specific date in April 2015 the products he was presenting ranged from vegan recipes, including his own cooking experiences, a Nokia smartphone, and a series of documentaries preceded by a trailer. ${ }^{12}$ The virtual parallel universe allows him to practise his skills as well as to develop and show off new competences. It also enables him to compensate for a lack of face-to-face contact with other people. As already mentioned, not even his illness can prevent him from operating in this universe; this is possibly where he can command the respect which he does not gain due to his absence in his so-called real life.

\subsubsection{Participatory Projects on Offer}

Like the 14-year-old blogger introduced in the previous section, a 22 -yearold blogger also discusses products for companies if she can keep them afterwards. ${ }^{13}$ Like him, she intersperses personal entries with advertising for these products. She does not only make a pitch for goods to be sold, like video games or a particular brand of headset, however; she also touts something different, something which cannot be bought but which involves participation. A quick analysis of her blog in April 2015 gave the impression that these participatory projects even had priority. She encouraged her readers to answer the question "How, when, and where do you prefer to watch series?" by describing their own experiences with TV series in her so-called blog parade. She prompted them to follow her example and put together a "retro toy mirror" which had a frame made out of small toys which she had spray-painted green. She sent round a "recycled flea market nerd box" out of which everybody could take the same number of things as they put back in. At the end of the game it would be returned to her. In addition, she set up competitions in which she passed

\footnotetext{
${ }^{12}$ Trailers are assembled from individual scenes in a film and last around two minutes.

${ }^{13}$ This is the second story which the 22 -year-old tells alongside her self-staging narration in Sect. 4.2.3.
} 
on the presents which she had been given by companies and she was also in the process of setting up a blogger network.

In contrast to the digital suppliers who provide goods which can be bought, the 22 -year-old posts ideas for products on her blog. Producing them requires cooperation or participation. She is not the only one who can win a potential prize in the form of a small present or having fun: Anybody who participates can win something.

She admitted that her motivation for organizing the participatory projects was the pleasure she gains when her ideas meet with a positive response. She was not so enthusiastic about negative comments. If anybody repeatedly left negative comments on her blog, she issued the following warning: "If it continues like that, your comments will simply be ignored or deleted." Otherwise visitors were naturally very welcome as potential participants. In order to attract visitors or readers to her blog, she regularly read and commented on other people's blogs, 355 in all. That would add up to approximately 300 posts daily which she at least skimmed through. Advertising and setting up her participatory projects requires a much more intense kind of interconnectedness than selling goods. The 22-year-old blogger may be the initiator, but the products themselves are collaborative in nature.

In the course of the interview, the blogger evaluated her actions from a moral perspective, saying that she thought that keeping presents from companies for herself was ethically questionable: “Even so, I don't only use my blog for such things but have to admit that I sometimes misuse it to get things for free." So sharing donated products with others appeared to be morally more acceptable: "Now and again I do something for my readers, it's not so that I always keep the products for myself, but now and again I give something away.”

In a similar manner to the digital suppliers, at least when they were only offering goods for sale, for her, digital space is a salesroom which she has turned into a sparkling setting for her product placements with the help of multimedia applications. Its network-like nature supports her wish to interconnect with as many people as possible. In contrast to the suppliers in the first group, she exploits the multimedia options to create a game out of supplying and selling products and ideas for which she then looks for fellow players.

The 22-year-old's training as a media designer forms an important backdrop for the structure and presentation of her participatory projects. Her own blog serves not only as a platform for putting what she has learnt 
into practice but also as a stage on which she can act independently and try things out which would presumably not be appropriate in a professional context. Another biographical detail could also be potentially significant for explaining the context of her participatory projects. When she was young, she lost her brother. She mentioned her brother's death right at the beginning of the interview when the researcher asked her about formative events in her childhood. Her response: "I may have been only six years old at the time, but I can still remember everything very clearly. ... How my family behaved, I can still remember that very clearly. I can also remember the day he died." Her brother's death must have represented a drastic loss for her which still affects her life today as she remembered it so vividly 16 years later. The participatory projects which she initiates on her blog are a kind of antithesis to these experiences, demonstrating her attempts to maintain relationships with others in contrast to her experience of loss. They could serve to compensate for the drastic loss which she experienced at an early age. But this is only conjecture. There are not enough empirical data to provide additional support to this argument.

\subsection{Narrations About Managing Boundaries}

In the narrations of network actors and bloggers which are about managing boundaries, boundaries act as a focus for thoughts and actions. Boundaries separate territories from one another, often running along embankments, waterways, and mountain ranges, and are visibly marked by border stones, border stations, and border guards. Boundary symbols of this nature are non-existent in the internet. Access to some apps may require registration and/or a password, but these barriers are easily overcome and are hardly even perceived as such.

The technology behind digital media has swept away the familiar geographical and physical borders and has turned virtual space into a boundless space, at least on the surface, as new borders are edging into virtual space, both from the outside and from the inside. In the stories told about managing boundaries, external barriers play a role in the form of sociocultural borders whereas internal ones correspond to individual needs. Whether we are dealing with external or internal borders, it is always a question of the division between the public and the private, which can also be linked to the division between online and offline. These borders collide with the proposition of a border-free digital zone, the collision becoming a challenge to act for network actors and bloggers. In the stories they tell, 
they take up this challenge; the narrators act as managers of boundaries. In other words, they want to decide for themselves, taking the detected or suspected risks into account, how to define the border between the public and the private. Characterizing them as such underlines their systematic approach and defines them as actors.

\subsubsection{Managing Boundaries as an Answer to Sociocultural Borders}

A 27-year-old Arab blogger told a story in which the collision between sociocultural borders and the boundlessness of the internet opened up by digital technology surfaced particularly clearly. She not only senses that disregarding external borders would be dangerous for her; she knows that it would be. She does not know the precise course of the sociocultural borders, even though she mentions topics in the course of her narrative which are socially taboo. The 27-year-old has to establish where the border runs for herself, possibly with support from the blogging scene in her home town, but no such support was mentioned.

The 27-year-old started blogging when she was 17 years old after establishing that most bloggers were based in the USA at the time $(2001 / 2002)$ and there were no blogs from Saudi Arabia. The shortcoming which she had identified was motivation enough she claimed: "And then I just thought, why not make a blog that is also from Saudi Arabia?" She did not say that she wanted to be present on the international stage of the internet as an individual, in contrast to the narrators of the self-staging stories, but that her home country should be represented there by her blog. This is the first indication that, as a blogger, she has located herself within a cultural framework which she cannot ignore because she has to take it into consideration in her online activities. She admitted that her awareness of this framework had increased over the previous ten years and that her early blogs differed considerably from her later ones: Earlier, she had posted entries under her own name; now she avoided publishing personal information, at least in the blog which addressed the general public directly. The 27-year-old was running three blogs at the time of the interview. She used one of them to keep in touch with family and friends scattered all over the world. She blogged every evening, reporting on the experiences that she wanted to pass on, explaining "[s]o it's something where I can share my life with them." Access to that particular blog was restricted to a group of people she knew whereas a second blog, a podcast, was for public 
consumption and particularly aimed at the inhabitants of her home town. She produced the contents during the week and broadcast the podcast every Friday. It was about life in her home town; she often invited people to participate and interviewed them about their lives in the town, one which she considered to have a relatively constructive atmosphere for discussion: "The city of [name $]^{14}$ has a reputation for being the most open city in Saudi Arabia; we are more open to modern things." But there were still taboos, she admitted: "Well, in the audio blog we talk about everything you can imagine about in [name of city] in Saudi Arabia except, except for religion and politics. These are two things that we never, never talk." It was not the case that she was not interested in these topics at all. Quite the opposite was true: "In fact, I enjoy talking about them." But she emphasized that these topics were reserved for face-to-face contacts offline: "You know, they're very, they are very sensitive topics in my society and I feel it's better discussed in person." The third blog was a photo blog, but she did not go into any detail about it.

The way in which she runs the three blogs reveals her strategy of drawing a line in virtual space between the public and the private by posting about different topics and making them available to different groups of people. The boundaries she draws are not restricted to virtual space either; they are also drawn between the space where discussions take place, namely online and offline. Public topics which would be risky to discuss in public online are consigned to private spaces offline. In addition, she draws a line between the public and the private in her offline life when it is influenced by her online presence. She does not want to be identified as the author of her podcast in public, for instance. She recounted:

For example, I would be at a supermarket or I'd be at a restaurant and someone would recognize my voice and say, 'Hey, aren't you on that podcast?' ... Most of the time I deny it and I say, 'No, no it's not me [laughing]. You probably mistake me for someone else'.

She justifies her behaviour by explaining that those who listened to her podcasts should react to the contents she presents there and not to her as an individual. She also indicates that it is not desirable in her country to become an online celebrity when she told the interviewer: "You would think that it's a nice feeling, because it's like being a celebrity, but in our

${ }^{14}$ The name of the town has been left out for reasons of anonymity. 
society it's not the same." Once again, the sociocultural framework becomes visible to which she has tailored her behaviour. The strategies she practises in separating the public and the private as well as her online and offline presence demonstrate that her actions are deliberate, which makes this a clear case of managing boundaries.

Strategic behaviour requires awareness, which also comes to light in the blogger's reflections scattered throughout her narrative. On the one hand, her reflections relate to her reasons for practising boundary management. In connection with not discussing politics and religion in public, she initially said that the reason for this was that she did not know enough about it:

I feel, I feel we don't have the right knowledge, we don't have enough information about religion and politics to talk about it. It's not our expertise-do you know what I mean? And it's not fair for us to talk about it.

This justification contrasts with another statement when she said that she enjoys discussing these topics in private. This contradiction can be solved if the blogger proceeds on the assumption that a public discussion requires extensive knowledge which is not necessary in a private conversation. On the other hand, the blogger speaks about regarding political questions as cultural issues because they are closely connected with religion. Religion belongs to culture; the discussion of cultural questions is possibly subject to fewer restrictions, as hinted at in the following passage:

I think it's more cultural than political, honestly. Saudi Arabia is, we don't really have much politics here that is not involved with the religion. The two topics are, they're very close to each other. ... So we try to keep it on a cultural level.

The last sentence speaks in favour of strategic behaviour with the intention of converting political questions into cultural ones so that they can be turned into something which can be discussed in public. This also suggests that attempts have been made to expand the space for public discussions in the internet as well. The self-imposed boundaries are, thus, flexible rather than rigid.

The reflections integrated in her narrative also relate to the blogger's Self. The self-imposed boundaries between the public and the private raise the question as to whether the different areas reveal different Selves within 
the blogger; in other words, whether there is a public and a private Self. The blogger has obviously asked herself this question too as she answered it in the interview, although it had not been asked, namely "I'm pretty much the same online, the same person online as I'm in person.... I feel like my life online cannot even be separated from my real life ... it's like a continuation." Even when different Selves may be present online and offline, the blogger does not necessarily feel as though she is fragmented, provided that she is aware of the different areas of her life and the Selves which evolve in each of them can communicate with each other. The blogger talked about the interdependency between the different areas of her life in the following passage, which can be interpreted as a communicative relationship: "Everything that I do online has a connection to what I do in real life. My interests, my hobbies, my friends-it's all very much interconnected."

The management of boundaries described earlier is closely connected to the 27-year-old's internet presence. "I'm 100\% an internet person" is how she describes herself. She already began using the internet when she was 14 and was given her own laptop at age 16/17. She describes the early days of her using the internet as a transition from keeping a diary to using the computer. That explains the importance of the blogs as a platform for expressing her life in words and images. She said that her daily blog entries were like writing in a diary every day with the crucial difference that these entries were addressed to an audience and thus questions about their public and private nature were pressing. At the same time, she is not uncritical of the medium, lamenting the deficits of digital communication in comparison with face-to-face communication: "Well, I think online there is a lot of things that are lost like maybe a tone of voice, maybe a facial expression and we tend to misunderstand a lot of things." Her awareness of such deficits could make her even more cautious when drawing the line between the public and the private so as to avoid risky misunderstandings in a public discussion online.

Despite her prudence, the 27-year-old could not prevent a collision with sociocultural boundaries. When she was asked about her most meaningful blog entry, she talked about one which she deleted after she had published it. Her story went as follows:

I wrote, I wrote a blog that is about racism. This is a very long blog post. I talked about racism in my city, which is something that we don't really talk about, nothing you talk about. And when I published that, it suddenly 
became a huge thing. People started calling me and asking me about how I felt and why, how did I have the guts to publish something like that, you know. I have deleted it, it kind of showed me the boundaries.

We did not find out whether the people who took offence at the blog entry were government representatives or other internet users; in either case, the reactions drew her attention to a boundary which she felt she had crossed. She considered this boundary to be insurmountable and deleted the entry. In retrospect, she had misgivings as to whether she had made the right decision, saying "I wish I didn't delete it." That speaks in favour of her attempts to sound out the boundaries of the public sphere and to move the boundaries which were defined from the outside, a possibility which she had not considered at first in the face of the fierce external criticism. One possible reason why she chose this blog entry as being particularly meaningful is because it sent her a clear signal in what was otherwise a largely indistinct area of external boundaries which she subsequently took into consideration in her actions. This does not mean, however, that she welcomed such a sign because she also explained: "I think one of the worst things about publishing yourself online openly is that people tend to judge you."

The fact that the 27-year-old turned the internet into an important location for her life is embedded in her specific educational history. She attended an international school where she learnt English so well that at the time of the interview she was writing for an English-language newspaper and was teaching English as well. Thus she is proficient in a language which allows her to communicate worldwide unhampered and she has mastered the technical skills as digital technology was already available to her when she was young. This facilitated her access to a space for communication which plays by different rules to the society in which she lives beyond the realm of digital technology. The blogger's management of boundaries is an attempt to deal with the differences she perceives in such a way that the risks are banished and new spaces are opened up to her for communication.

\subsubsection{Managing Boundaries as an Individual Need}

This type of narration about managing boundaries is also about dealing with boundaries but this time they are not external, stemming as they do from individual needs. These needs also relate to social expectations, 
which are, however, much hazier than the sociocultural boundaries described in the previous narration by the Arab blogger. In the following narration by a 19-year-old European network actor, chosen for its prototypical nature, it is not the problematization of externally set boundaries and attempts to shift them which dominate but the boundaries the network actor draws in the interests of improving her own chances. These personally defined boundaries serve to demarcate the private from the public, but in contrast to the first story about managing boundaries, the sole focus is on a depiction of the blogger herself and not on a discussion of political topics. Issues relating to revealing and concealing oneself occupy centre stage, but they give rise to ambivalences as revealing oneself has both its advantages and disadvantages.

When the network actor set up her first home page at the age of 14, she already used it as a platform to present herself and her preferences, she admitted. It included a list entitled "What Margarete" likes, what Margarete doesn't like." She also put a photo gallery on her home page, including photos of her room, and a page where she published the computer games she played and the texts of songs she listened to. At the time of the interview the 19-year-old was active in social networks. On Facebook she posted photos of her trips but also her own poems. In her status updates she shared "when I am travelling somewhere or what I'm thinking about." When she went to an event, she "automatically" posted that on Facebook as well.

Digital media, it would appear, document her life but not her entire life. She described how she selected what she related and how, with the intention of creating a positive public image of herself:

Well, I don't want to post any old thing online which I myself don't like or which presents me in a bad light somehow. You always make yourself a little bit more beautiful somehow, when you have the possibility to present yourself.

For this network actor, it is all about the "beautiful image" of herself which she wishes to create in the public space of social networks. She admitted that if something did not fit in, she kept it to herself, deliberately drawing a line between revealing and concealing herself, as is quite clear from the quotation which, at the same time, represents the boundary

${ }^{15}$ This is a pseudonym. 
between the public and the private. By changing from the first-person singular pronoun $(I)$ to the second-person singular (you) when talking about the sugar-coated self-portrayal, she characterizes her conduct as general behaviour. This possibly allows her to own up to this behaviour although she is well aware of its problematic aspect, as the following experience shows.

Drawing boundaries in the interests of creating a beautiful image can become problematic when another boundary is crossed in the process, namely the boundary between digital space and the world beyond that space in which face-to-face encounters dominate. The network actor told a story from the time when she had just begun to be active in the internet. She related how she got to know a girl in a chatroom "who I then wanted to meet or she wanted to meet me and then I didn't want to. Well, it was like this, for me, I suddenly didn't dare to meet her." She did not dare to meet her because she was aware of the discrepancy between the image which she had created of herself online and the image which she did not make public. It even appears as though she perceived the beautiful image to be a false image when she said: "I got in the habit of presenting myself as somebody who maybe wasn't me." The fact that she dared to do so online, I would presume, was because the "virtual and the real" were separate in her head. When faced with the up-coming meeting, the boundary between online and offline threatened to liquify. There are also indications that she was uneasy about the meeting from the very start because she was not clear about who wanted to meet whom and whether she really wanted to meet the other girl. Ultimately she prevented herself from crossing the boundary from online to offline by evading the face-to-face contact, which she presented as a drama because she cancelled at the very last minute. Up until that point she had hesitated, only to confirm the boundary present in her head in order to keep the beautiful image intact.

Even as a 14-year-old, she saw how having her own home page gave her the option of determining her own public image. She exploited this option, from her perspective, to "portray myself in a positive light." Against the backdrop of this motivation, it is hardly surprising that she developed a methodological and intentional plan of action when dealing with boundaries in virtual space as well as between so-called virtual life and real life which involves management skills. 
This behaviour promises her the responses that she treasures. They trigger a feeling "like Oxytocin," 16 she explained, "and that is the same feeling you get when having a cuddle [laughing]. And that really triggers a feeling of happiness." The feeling of happiness is not long lasting, however. She recounted how she felt anxious when she became aware of the fact that the audience for her electronic messages was unlimited and that her online profile could be accessed anywhere any time:

I was at a party recently and I was standing near the TV in the living room where you could look at Flickr albums ${ }^{17}$ and suddenly they started to look at my Flickr album and that really was, that was a bit weird.

The interviewer asked her what she felt like in such a situation. "Well, pretty unpleasant at first," she replied, "because there were photos of a photo shoot together with a friend. And then all of a sudden I wasn't sure whether she also was in favour of me posting it online so that others could see it." The 19-year-old had unexpectedly become witness to her own online presence; she was forced to look at herself from the perspective of an audience, taking over their standards and measuring her own image by them. That can be quite unsettling. She also realized that she had publicly posted pictures of her friend online without asking her for permission.

There are no general rules for the constitution of new public spheres in virtual space. Everybody has to decide for themselves where they draw the line between the public and the private. The 19-year-old had relieved her friend of this task, possibly disregarding her friend's idea of where the line should be drawn in the process, she now realized. She identified her mistake; we do not know whether she took appropriate action. The doubts that briefly arose on having posted her own picture soon gave way to a positive assessment, as the following statement shows: "But otherwise I actually find it pretty, well somehow fascinating to see how they react. Because then you also notice what people actually like and what not when they look at it." As a direct witness of the reactions to her own photos the network actor found out what she could do even better, how she could appeal to public taste even more. This situation which started off by

\footnotetext{
${ }^{16}$ Oxytocin is a "feel-good" hormone which is associated with love and trust.

${ }^{17}$ Flickr is a web portal where digital images and five-minute videos can be posted and shared.
} 
unsettling her, in the end, accommodated her motivation to create a positive image of herself.

And yet she still has doubts as to whether the boundaries that she draws are drawn appropriately. Looking back on the boundaries she drew between the public and the private as a 14-year-old network actor, she wondered "whether I should have actually disclosed that?", continuing "[y] ou have to ask yourself how much you should post online these days." She mentioned this right at the beginning of the interview, indicating that the question of managing boundaries is uppermost in her mind. Towards the end of the interview, she reformulated her scepticism even more clearly, comparing her generation with a generation which does not have an online presence in her eyes:

When I think about it, the grown-ups of today don't have their past on record. You can't actually find out anything about them online because the internet hasn't been around long enough; well, nothing about when they were young at least.

This comment sounds as though she is envious of the generation described as not having an online presence. Contrary to this generation, she sees her past as being on record in the internet. A "past on record" is like handcuffs which can bind her to an unloved spot, which she cannot throw off, which can also operate effectively in the present, whether she likes it or not. Thoughts along these lines appear to stick in her mind: "I don't know whether you ... can keep track of me for ever. Actually I can never ever reverse it and that's somehow a bit crazy." These words reveal the uncertainty in her mind as to what can happen with her public image, what access it will be exposed to, things that she cannot prevent from happening because she has entrusted her image to a medium which stores all content on a permanent basis, like an archive. That is how she sees it at least. In response to the researcher's question "I am present on various online platforms. What does that look like for me?", she drew a picture which visualized both her uncertainty and her attempt to protect herself from unwanted access (Fig. 4.4).

In this drawing there are many arms and hands to be seen which are all clutching a figure, well wrapped up like a mummy, with only the head sticking out. She described herself as the "little doll with her Mac, typing away to herself, with her eyes closed and looking down, actually." She could feel the arms and hands coming from outside, but she did not want 


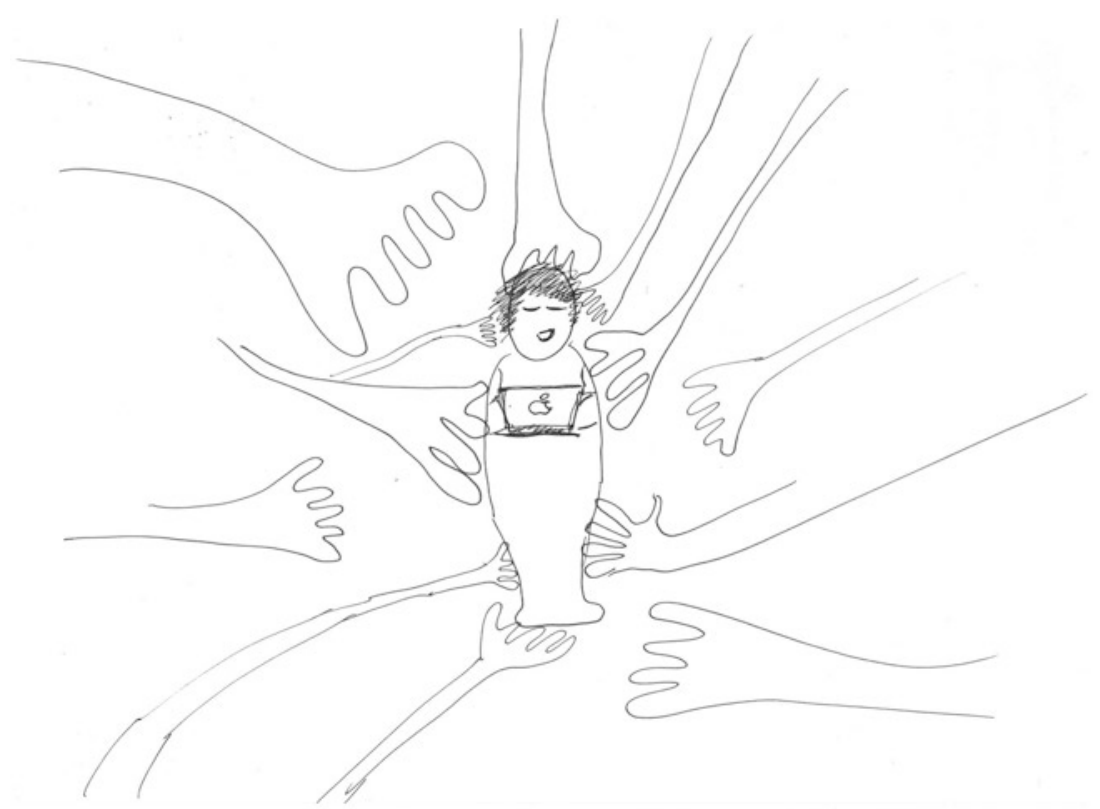

Fig. 4.4 Retreat into the private amidst an anonymous public (network actor, f, 19, Austria)

to look at them, pointing out that the arms did not have any faces. They represent an anonymous public. By looking down and not being able to see herself, she can cherish the illusion that she cannot be seen; as a mummy-like figure there are few opportunities to attack or access her. The drawing creates the impression that she is retreating into her private world while surrounded by an anonymous public. This conflicts with her need to use the digital stage to be able to present herself to the general public in a positive light. She can live with this contradiction. It makes her think. She searches for reasons to publish personal details, also seeing them in the appeals launched by social networks like Facebook: "They pretty much urge you to reveal everything about yourself." She has followed these appeals so far by showing online what can serve to construct a beautiful image. We do not know what the future will look like: The thoughtfulness which we identified and the doubts expressed about the way she has 
managed those boundaries so far lead us to believe that the 19-year-old is undergoing a period of change in her life.

This network actor discovered the internet for herself when she was 14 years old; she did not regard it as a tool but rather as a new place to live: "I spent my whole life there then, the whole day, I was really addicted to it." Looking back to her early days in the internet and to subsequent experiences, she wonders whether she identified the correct boundaries. In a similar fashion to the Arab blogger in the previous story about managing boundaries, she is concerned about identifying strategies which should protect her from the risks of unauthorized access without wiping out the potential for accessing a new public.

\subsection{Transformation Narrations}

Changes from one life phase to another or changes in self-representations are the focal points which the transformation narrations revolve around which were identified in the study "Communicative Publics in Cyberspace." The protagonists in these narrations are between 11 and 13 years old. They sense that something is about to change, that they should and/or want to become an Other. Intellectually, actively, and emotionally, they are setting off on a voyage of discovery in which digital media take on important functions in several respects. Even mere possession can serve to document the process of change in a visible manner; digital media are also used as an experimental space, training venue, or template when making decisions about questions concerning real life. Woven into their online actions are moral questions and questions about the Self as well as questions about success and respect.

\subsubsection{The Goal-Oriented Actors}

Both of the narrations embedded in the interviews with a 13-year-old and an 11-year-old network actor, both male and from the same Germanspeaking country, have a clear common objective, which should be conveyed by the heading "the goal-oriented actors." For one of them it is quite simply the goal of becoming an adult; for the other it is the marks of success and bonuses which are associated with becoming an adult. The 13-year-old wants to leave everything behind which identifies him as a child and surround himself with symbols of the adult world instead whereas the 11-year-old is trying to attain his goal of becoming a famous 
football player. For the 13-year-old, the symbols of the adult world include increasing his access rights to the internet and owning (media-related) technical devices whereas the 11-year-old is busy practising his football skills on the pitch, on the street, and in the internet. Both protagonists were included in the study because they were members of SWR Kindernetz (2020). ${ }^{18}$ But by the time the interviews took place, several months after they had been selected, they were only using the network sporadically or were distancing themselves from it. Their growing detachment from SWR Kindernetz corresponded to their efforts to conquer new ground.

Right at the beginning of the interview, the 13-year-old distanced himself from a computer game that SWR Kindernetz (2020) had put online, explaining that he used to play the game and called himself "Löwie" in the game but that he had dropped the nickname and hardly played the game anymore either. A little later he referred to a second computer game where he could interact with a frog and a tiger duck ${ }^{19}$ which he had also turned his back on. His justification for no longer having fun playing it was: "As I said, I think that it's more for younger kids." The 13-year-old wants to act independently, which also becomes clear in the part of the narrative where he described how he came into conflict with the editorial team of SWR Kindernetz (2020). He explained that he had breached rules on the network on several occasions, for example by including a Playboy symbol made up of dollar signs on the home page which he had set up on the portal. He then removed the symbol from his home page but uploaded it again the following day. He had not been reprimanded a second time. The 13-year-old thought that his actions were funny; he attested that the editorial team were "nuts." The incident he described was all about negotiating power. Virtually still a child, he was wrangling with adults about who had the authority to make decisions. For the time being, the 13-year-old could assume that he had won the power game, which he could chalk up as a gain in status.

Whereas the examples described earlier concern the use of digital media, which provides evidence, in the eyes of the 13-year-old, that he is growing up, he emphasizes in other passages that owning (media-related) technical

${ }^{18}$ SWR Kindernetz (2020) is a portal for children aged 8 to 14 which has been run by the Southwest German Broadcasting Company (SWR) since 1997. At the time of the interviews in 2010/2011, its online offer included a media network, an information section, an online meeting point, and a games section. The network was moderated, but the children could also set up their own clubs and home pages.

${ }^{19} \mathrm{~A}$ character in a children's book created by German artist and author Janosch. 
devices should prove his transition to adulthood. He recounted that he had bought a "brand spanking new" mobile phone which was "bloody expensive" but he wanted to have a "fast and good mobile," and his pocket money obviously sufficed for the purchase. In addition, he had "got hold of a new screen" for his PC. At the time he was looking around on eBay for a scooter because he wanted to "get hold" of one the coming year. "Yes, then I'll be able to ride a scooter," he said, adding that "I'll get one with my pocket money as well." It is not only the fact of owning such (media-related) technical devices by which the 13-year-old is catapulting himself into the world of adults; in order to participate in this world, having his own money also appears to be of importance as it allows him to behave like a consumer.

No less goal-oriented, the 11-year-old pursues his path into the world of adults, albeit by different means. He is not interested in owning status symbols and having rights but in improving his skills as a football player. $\mathrm{He}$ is not only a member of a football club in the real world; he also takes part in football role-playing games provided by SWR Kindernetz (2020). He related how he swapped information online with other internet users about football clubs, players, and trainers; he also watched videos about football games online. And when he himself played football, "then I try to play like them, so I also copy their tricks." He described how he took on the role of admired players, became a star himself, as long as he was online at least, and experienced "what it feels like to be famous." He went even further, wondering "what he [Miroslav Klose, for example, a former member of the German national side] does in his free time, whether he's somewhere online in the internet." He followed his role models on Twitter. He was not only interested in their qualities as football players but also in how they lead their lives. His role models stand for a specific life model which he aspires to, as will become clear.

What motivates the 11-year-old to follow in the footsteps of his role models so passionately? He knew just what it was. He wanted to be famous. "Famous?" inquired the researcher. "Yes, famous, yes, yes!" he replied and continued:

I think it's just great when you're famous and hear a lot about yourself, that you're in the media, on television, in the internet, in computer games as well, that people know a lot about you ... that you're also famous all over the world. 
The 11-year-old would like to be at the focus of media attention, admired, and maybe even envied, an important person for many. He expects that fame would also bring about something else, namely the possibility to earn a lot of money. He found that "it would certainly be good if I could buy myself great things with my money." By "great things," he means new gear. "Well, clothes are important to me," he explained. At school it was very "in to wear cool gear." He would like to have brightly coloured clothes, "yellow, light blue, blue, red" and sparkly stuff, like some girls wore in his class. He was crazy about "a lot of small diamonds, maybe, well okay, stones that glitter, that gleam in the sun." He did not have any clothes like that himself because they were too expensive. But he had given himself a nickname that brought him closer to such gear. He called himself "Hardyboy." Hardy was his favourite brand of clothes, although he did not actually own a single piece. The 13-year-old, in contrast, did not go into his motivation to strive for an increase in his access rights to the internet and to own more (media-related) technical devices in such detail. They were concealed, more implicitly, in the descriptions of what he did. He would like to replace childhood things with adult things but he did not say why adult things were so important for him. He did not mention the ideas he associated with being adult in his narrative either. In a similar way to the 11-year-old, it could be the feeling of being acknowledged that he wishes for. But there is no evidence for that in his interview.

Neither of them speaks explicitly about feelings when they talk about their goals and how they will achieve them. They disclose themselves implicitly, however. The 13-year-old is clearly proud when he lists the (media-related) technical devices he owns, when he emphasizes that he could afford to buy them with his pocket money, and when he compares the merits of his new possessions with the "old crap" which he has abandoned. The enthusiasm of the 11-year-old comes across clearly when he imagines being as famous as some of his favourite football stars or when he describes the glittering stones which he discovered on the expensive clothes which some of the girls wore in his class. Feelings of longing are also likely to be part of him as the things he admires and the things he aspires to are quite a long way away for him. Feelings of fear and frustration cannot be ruled out for either of them as the paths they have chosen to tread are paved with uncertainties, which makes setbacks likely.

In contrast to the 13-year-old, the 11-year-old sprinkles his narrative with reflections on the reasons which should explain his preferences and activities. He particularly tries to work out why he prefers football and 
remembers: "I always was very sporty, for as long as I can remember." $\mathrm{He}$ started playing football when he was three or four. "Actually I grew up with the ball," he said. He was particularly fascinated by the moves, probably because he was good at them himself. He continued to explain: "You have to move around a lot, you see. You also have to run and be in good shape. And well, I am fit and that's what I like about it." He gave a second reason for his enthusiasm for football, namely the aesthetic qualities of the ball. He thought that the ball was "a very beautiful piece of sports equipment." This eye for beauty provides a link to his enthusiasm for brightly coloured, sparkly clothes and could represent the dreams of a young boy who would like to accomplish a great deal in the future.

Both boys pursue their strategies, which are geared towards change, online and offline, deliberately integrating digital media into their strategies. These media have qualities which turn them into a central location and tool where and with which the shift from childhood into the adult world is decided. The 13-year-old was given access to the internet on his 11 th birthday, which he could interpret as a sign of growing up, but, then again, his father "activated the parental control function so that I can't access all homepages." This function appears to matter a lot to him because he mentioned it in the interview time and again, including the fact that he gauged his biographical status by it. Shortly after he had mentioned the parental control function in the interview for the first time, he declared with relief: "Now I've not got the parental control function anymore." His father had removed it because he assumed that the boy would now manage to find his own way around the internet. With pride he recounted: "And then I got everything, all of the programs: Microsoft, Outlook, and everything else were installed by my father." Having said that, he also mentioned that he was still not allowed to use the social network SchülerVZ, ${ }^{20}$ although he found it "cool" precisely because his father did not let him use it. It could be that his initial perception of having the entire internet at his disposal was somewhat exaggerated, but that would only serve to underline that the removal of restrictions, in connection with the trust his father placed in him that he would deal with this in a responsible manner, was crucial for him when determining where he could place himself on his biographical "ladder of life." A further function, which was already discussed earlier, relates to the possession of (media-related)

\footnotetext{
${ }^{20}$ SchülerVZ was an online community for pupils which was founded in 2007 and which closed down in 2013.
} 
technical devices, where digital media count as a materialized expression of becoming grown up, along with the scooter and television.

For the 11-year-old, the digital media are important for training and looking for information. As already mentioned, football role-playing games give him the chance to practise his skills as a footballer whereas on social networks like Twitter and YouTube he comes closer to his idols by following their digital trails in words and images. Towards the end of the interview he mentioned another opportunity for training provided by digital media, namely communication with girls. In digital networks he dared to do things he would not dare to do face-to-face. Online he could "pretend a bit and say, 'Hey, how are you doing?'." In real life he would "never get it out ... properly because I'm a bit shy." For him pretending obviously means that he comes across as being more courageous than he actually is. His courage would fail him if he "was standing in front of them in real life." Possibly he is worried about how to deal with rebuffs which he would need to react to immediately in face-to-face contact. In such a situation the little boy would be visible who can hide himself online behind words and pictures. But maybe the little boy will also become more courageous when he has had enough practice in the internet.

The transformation narrations of the two boys should be seen in the context of a life phase characterized by upheavals and transitions. Childhood is coming to an end and adolescence, which leads to adulthood, is in sight. They are confronted with new, external hopes and expectations or have a presentiment about them; sometimes these expectations become tangible, like in the case of the parental control function being removed, accompanied by the appeal to behave responsibly online. More often than not, these expectations remain vague. The two boys face this unclear situation with clear objectives which they resolutely pursue.

\subsubsection{The Role Player}

Like the 11-year-old boy, a 12-year-old girl also talked about her preference for role-playing games. But in contrast to the boy she does not just slip into one role but takes on many different roles online and offline, including roles which she said would not go with her personality. The 12-year-old is trying things out; she has not yet made a decision. She is struggling with the question as to which one is right for her, and the digital media help her to come closer to her answer. 
She explained how she joined SWR Kindernetz (2020) because of the role-playing games, which proceed as follows: Everybody taking part in the game gets a role whose character is not represented visually but is described in words by the moderators or players themselves. Between 10 and 50 players participate in one role-playing game. Together they write a story in which the players take on specific roles. When asked by the researcher which role she played, the 12-year-old replied: "Usually I am a normal person and rather a girl, of course, but sometimes a boy, too." This network actor does not want to become too detached from the reality which she thinks of as being normal but she does flirt with the idea of the Other as well, for example when she reported that she sometimes played "the bimbo" although that was not what she was like "for real." As a bimbo she had long blond hair, wore shorts or miniskirts, teased the others, and considered herself "totally gorgeous." Although such behaviour did not correspond to her self-image, she found it "exciting to play that role." It could also be exciting to try out another personality, allowing her to experience new feelings and thoughts as well as other players' reactions, which could also reveal a few surprises. The 12-year-old was taking part in seven role-playing games, slipping into a different role for each of them, which also opened up a broad spectrum of possible experiences and actions.

Beyond these role-playing games, the 12-year-old slipped into another role as the organizer of an online drawing club. In this club, which has 20 members, they swap their experiences of drawing, advise each other where they can buy the best coloured pens and pencils, and discuss how they can learn specific techniques. The 12-year-old is in charge of this club, as she describes thus:

So, when somebody new wants to join, they have to confirm that they are allowed to become a member of my club and I can set up a poll where you have to answer with yes/no or in/out. I can delete posts in case the rules are not-well, in case they break the rules. Yes, it's like that!

Alongside her drawing, in this role she can practise her organizational skills, leadership abilities, and powers of assertion (Fig. 4.5). When asked about the motivation behind founding the club, she explained: "I would like to get better, the way in which I draw and paint, that's actually the most important thing for me, and also that others get better as well." The second motivation, which relates to Others, is part of the role of being 
Fig. 4.5 On the lookout for the right thing (network actor, $\mathrm{f}$, 12 , Germany)

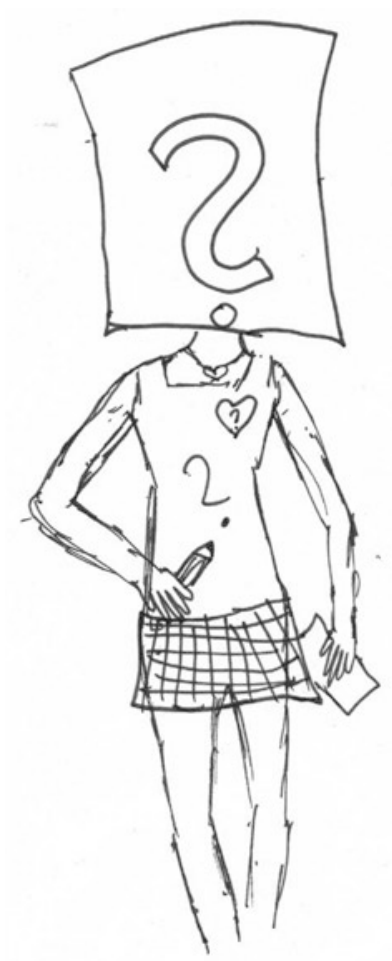

club leader, responsible for choosing suitable members, asking about their interests, and ensuring that everybody sticks to the rules. An overarching motivation for the 12-year-old's online activities is implicit in her visualization, which answers the question "Who am I in SWR Kindernetz?"

The drawing shows a female figure whose body is drawn in detail whereas the head just consists of a rectangle with a question mark in it. There are also two question marks on the figure's torso. In one hand, the girl is holding a pen, in the other a piece of paper; both reveal what the 12-year-old likes doing, namely drawing. She commented on her visualization as follows:

The question mark should symbolize that not much, well, that people don't know that much about me. And the one and only thing that they know about is what I like doing, and I've got that in my hands: drawing. And 
actually I should put a whole lot more question marks all around because they have no idea what I look like, just what I like doing.

Indeed, for the participants in the role-playing games and the members of the drawing club, she is primarily present as a participant; the Others only find out things about her through what she does. They do not know what she looks like for there is no picture of her in SWR Kindernetz (2020) and the brief description of her appearance there does not match her actual appearance. She herself appears to have a nuanced image of herself, however, as revealed by the detailed drawing of her body. It is not a childlike body but a body transitioning from a child to a young woman. This body symbolizes a possible goal which has not yet been articulated. The head is concealed, though, even for the illustrator herself. The question mark instead of a head could point to a personality which is still concealed, especially in connection with the two question marks at breast height, a personality the 12 -year-old is still seeking in her role-playing games. If this is the correct interpretation, then she herself is the one who does not yet know how her personality is going to develop but also the one who would like to find out about it, which could explain her experiment with many different roles.

Feelings are addressed just as indirectly by the 12 -year-old girl as by the two boys in the stories about the "goal-oriented actors." But here, too, there are implicit references to feelings. The motto on her home page reads "A day without smiles is a wasted day," which points to her need to enjoy life and to experience funny things. The way her motto is formulated is a constant reminder to pay attention to such things. Even her nickname "Sahnekeks" [cream cookie], which she made up herself, has an amusing ring to it.

More clearly than feelings, constant questioning is a feature of the interview with this network actor, in other words, a constant need for reflection. Running like a golden thread throughout the interview, this need concentrates on the question of identifying the right thing; a comparison between life online and offline should help her to find the correct answer. Right at the beginning of the interview, she mentioned that there was a theatre group at her school which she acted in. Immediately after that comment, she started to compare acting in the theatre group with online role-playing games, ascertaining that "you can get into the spirit of it better in the theatre group but participation in SWR Kindernetz, that's also nice." A few minutes later, she explained that acting in the theatre 
group was “much nicer ... but in SWR Kindernetz it's simply easier because you only have to switch on the computer; there [at school] you actually have to go there and you don't always have enough time, of course, it's completely different." She grappled with the question as to what was different on multiple occasions. In her view, the longer she thought about it, the difference between acting in the school's theatre group and participating in online role-playing games or the difference between communication in the two spheres of reality in general could be attributed to physical presence in the one and not in the other. She began her musings on the presence or absence of corporeality with the following statement:

In $S W R$ Kindernetz you don't see the other people who play a role, well actually, you don't see anything about them but only the description of the role; in the internet ... you have to write and in the theatre group you have to express your role with facial expressions and gestures and writing is just something completely different.

Communication by phone at least offered the possibility of hearing somebody's voice, with the consequence that

you know more about the others when on the phone, you know their voices ... you know their moods. When you chat online, you can't add intonation to the voice and that's what tells you about somebody's mood when they're talking.

The voice provides information about the mood; chatting, in contrast, makes it possible to cheat. She pointed out another difference which also has to do with physical presence, namely that she could not do things with her online friends, like having an ice cream or going to the swimming pool. So finally she came to the conclusion that it was not possible for her "to have proper friends" in the internet; that was why she "didn't set great store by friends in the internet." She even went one step further: Whereas there were many important things in "real life," in her view "in the internet ... actually nothing is truly important." In the 12 -year-old's reflections, the body becomes a guarantee for what is true and important because "it can't lie." Physical invisibility in the internet, in contrast, opens up opportunities for pretence and lies, which the 12 -year-old finds irritating. Then again, she makes use of these possibilities herself in her 
role-playing games and appreciates them because they lead her into new experiential worlds. It is not surprising that she is sometimes torn between both spheres when trying to evaluate them or that she contradicts herself at times. She justified setting up her online drawing club, for example, by saying that she wanted to improve herself; at another point, she explained that it was not possible to learn anything online "that you needed." Her answer to the question as to what the reactions of other internet users to her online profile mean to her was also ambivalent. "Well, it's not unimportant," she said, "but not truly important either." The reactions are only important when they are negative. And she deleted those, she said. Most of the time they included praise, or even offers of support when she was sad. But that was of no real help to her because the Others did not know the context which had caused that particular mood. They could not try to understand a conflict with her mother, for example, because they did not know her. She does not expect very much from a counterpart who does not share her social context. It is therefore hardly surprising when she responded to a boy who asked her online whether she wanted to be his girlfriend with a resounding "no": "I asked him whether he can't look for a girlfriend in his real life and that I found it quite rude of him to just ask and that we don't even know each other," she reported. Relationships which go beyond mere role-playing games need a common social context, or at least that is how I interpreted the 12-year-old's reaction, in which they have more in common with each other than posts in the internet.

Like the two boys in the previous section, the 12 -year-old girl is in a phase of biographical upheaval and transition. She, too, knows, what is important to her: the right thing or the "real" thing, as she put it. She is still trying to identify what the right thing is, though. The only thing she knows is that she does not want to be confronted with lies and pretence. In her eyes, the virtual world provides more opportunities for lies than face-to-face encounters, but at the same time, it is those very opportunities which allow the game to take place with different patterns of behaviour and facets of personality out of which the contours of a new I can emerge. It is this quandary which has become a challenge for her. 


\subsection{Stories About Setting Out and Breaking Away}

In the stories identified for setting out and breaking away, ${ }^{21}$ an existing life course or social model is contrasted with something new, involving either confrontation or a deliberate quest. The morphology of the German word Aufbruch emphasizes that it signals the beginning of a process. A flower, a bud, or even a wound can burst open (Grimm \& Grimm, 1854/1984, p. 630). An Aufbruch can be joyful or painful. The word Ausbruch indicates a sudden, powerful occurrence, as suggested by a fire breaking out, or a thunderstorm, volcano, the plague, a rumour, a disaster, or a war (1854/1984, pp. 53-54). Setting out and breaking away are often combined with each other in the stories told by the network actors and bloggers. They can appear as a biographical project, which can be embedded in an educational context, or in relation to a political project. In the biographically motivated contexts of setting out and breaking away, it is a question of combining the old and the new with each other; in the politically motivated contexts, those involved want to break away from something old that is experienced as shackles or associated with painful experiences, as illustrated in the Brothers Grimm's German Dictionary, which challenges the reader to "not let pain wear out your noble heart without saying a word, let it break out" (1854/1984, p. 54).

In these stories, regardless of whether they are dealing with biographical or political projects, the actors' thoughts and actions are futureoriented. Feelings of insecurity and uncertainty accompany this orientation as the consequences of taking action are unforeseeable, after all. The actors in the politically motivated contexts are infinitely more vulnerable because they are exposing themselves to risks affecting their health and their lives, as will become clear from their narratives.

\subsubsection{Setting Out and Breaking Away as a Biographical Project}

The authors of the biographically motivated stories about setting out and breaking away were 20,21 , and 24 years old when the interviews took place. Two of them were students-from Turkey and the USA-whose

${ }^{21}$ The original heading for this section is Auf-und Ausbruchsgeschichten. The play on words in the German verbs/nouns aufbrechen/Aufbruch (bursting open) and ausbrechen/ Ausbruch (breaking out) is difficult to reproduce in English so setting out and breaking away are used respectively, even though they do not cover as wide a range of meanings as the German words. 
stories are part of an educational project, and the third one, a 24-year-old American, was a globetrotter. Whereas the 20-year-old Turkish student was participating in a student exchange programme which took him from Istanbul to Vienna, the 21-year-old American student was a participant in a computer-based university project entitled "Global Modules" (Scudder, 2008, pp. 109ff.) in which students from the USA had online discussions on current political topics like peace politics, consumerism, or totalitarianism with students from other countries within a specified time frame. The Turkish student's setting out can be seen as geographical whereas that of the 21-year-old American was mental in nature. The 24-year-old American globetrotter also crossed geographical borders after setting out for Europe some three or four years previously where she had travelled through several countries, spending longer periods of time in some of them.

In the stories which were told, the old and familiar is found in the form of the narrators' home countries, their families and friends, and the new is found in the form of another country or another continent, including the people who live there and their cultures. Their attachment to their previous lives is important for the protagonists in these contexts of setting out and breaking away: The familiar social connections are maintained, and, at the same time, they want to get to know people from other social and cultural backgrounds, exchange views with them, and make new friends. The notion of setting out is more pronounced than that of breaking away, especially as there appears to be very little preventing them from tapping into new spheres of life, with the exception of their own pangs of guilt. The narrators of these stories are driven by curiosity, interest in Others, and expectations of improving their chances in life. The main experience that is associated with their intention to set out is that of a diversity of experiences.

Part of the setting-out story for the 20-year-old Turkish student involved his setting up an account in the social network Netlog (2010), which had been recommended to him by a friend for rapidly establishing contacts in the host country. He recalled that whenever he offered his friendship to Others in this network, he wrote: "Hello, I'm still new to Austria. I come from Turkey. I want to get to know people. How are you doing?" He could communicate in German, English, and Turkish, which shows that he wanted to get in contact with as many people as possible. He was not only interested in online contacts; he also wanted to meet people who were on social networks face to face. In order to counteract the potential transience of such contacts, he was quite resourceful. He 
offered: "If somebody wants to learn Turkish and as I want to learn German, we can do a tandem." He recounted that he had regularly met up with a German friend in a café; they spoke in Turkish and German with the aim of learning the language spoken by the Other. As a counterpart to his attempts to learn a new language, get to know new people, and explore a new country, he read Turkish newspapers every day in the internet and Skyped with his family in Istanbul every second day. His comment on that was: "I can see my family and that makes me happy. I really look forward to it."

The setting-out story of the 21-year-old American student took place as part of the university project mentioned earlier in which American students discuss current social issues with students from other countries. The 21 -year-old had already taken part in the project three times. Contrary to the Turkish student, for him it was not the personal contacts which were in focus but rather the international exchange on various topics. In this exchange he was not acting as an individual but as the representative of his university and country. "You feel an obligation to make a good impression for your school or for your country," he reported.

The 24-year-old American opened herself up to the way of life in the new countries she was travelling through in pictures. She took photos of everything which caught her attention, for example posters, "a man with a funny hat," or what she ate. She recalled: "I take pictures of my food that I eat in different countries ... It's an easier way to put things together." Her statement points to an attempt to find connections between new and different things in visual form which she discovered after setting out for another continent; in other words her aim is to generate coherence. This intention is also reflected in her habit of attempting to stay in touch with people whom she met en route via Facebook. In this way she creates a circle of friends who, virtually at least, accompany her on her journey and give her a feeling of coherence. The photos that the 24 -year-old posted online not only symbolize her setting off into a new world; she also used them to build a bridge to what she had left behind. She emphasized that the pictures which she had posted online could be viewed by her family. In her imagination, her family was participating in her story, becoming part of her project.

The strongest motivation in the Turkish student's story about setting out is the desire to find new friends and to build up a network that could maybe provide him with a new home; he does not see this as competing with his existing home but rather as complementing it. Initially, for the 
American student, it is a case of providing a good presentation of his country to people from other countries. But it does not stop there. In this attempt, he opens himself up to the Other, as represented by the people he is talking to, and gains, from their perspectives, new insights into the Own, a point which will be discussed later in more detail. In the 24-yearold American's story, the motivation for setting out is represented by the strong desire for freedom which she had already developed as a child, as illustrated by one of the stories she told. Back then she would have liked to play football with the boys but was not allowed to. So she took appropriate steps, as she put it:

I wanted to play football with the boys but I wasn't allowed to. If I can't play football, I'm gonna read a book. They think I had social problems but it was really because I wanted to play football instead of hopscotch.

Her determination not to be forced to do anything but rather to pursue the Own became her maxim: "If I had to do something, I never wanted to [do it], but I would do just about anything [I wanted to] willingly." This determination must have played a role when setting out for Europe, which does not mean, however, that there were no open questions for her.

"I feel guilty all the time," the 24 -year-old admitted. Her guilty feelings related to the younger siblings she had left behind in America and to whom she was like a mother: "I loved to play mother. I was always very involved in their lives." As much as she took pleasure in this role, she gave it up by setting out for Europe; emotionally, it appears, she had not yet freed herself from this role. As already mentioned, the Turkish student looked forward to speaking with and seeing his family in his Skype video calls. He was more worried about the here and now in his host country, Austria, tormented by the uncertainty as to whether he would make friends there, as the following passage illustrates: "I thought ... when they [the people in Austria] are not friendly, what will I do then? When I've not got any friends, what will I do then?" For the 20 -year-old, friendships appear to form the basis with which to minimize the risks of his setting out, but it is those very friendships which are unsettled by the new situation. Old friends have receded into the distance; new friendships have not yet been cemented. In this respect, setting out in a new country is not only like a bud bursting into flower; it can also lead to injuries, as indicated in the Brother Grimm's dictionary with the example of "a wound bursting open” (Grimm \& Grimm, 1854/1984, p. 630). 
The Turkish student's emotional insecurity gives him pause for thought: "Austria is in Europa and maybe its inhabitants are a bit cold." He makes a clear distinction between his home country and his host country; his words seem to imply that the different national identities could have consequences for the emotional behaviour of the inhabitants of both countries. These thoughts contradict his experiences in the social network Netlog (2010), however: "I use Netlog and I look at these people and the Austrians are not so cold." The concrete encounters which his setting out has prompted him to make confront him with the gap between expectations and experienced reality. The American student is also obliged to reflect on the concrete, albeit virtual, encounters as part of his university's online project, in which perceived differences are central. Initially only interested in the online encounters with people from other national and cultural backgrounds in order to present himself in the best possible light, he suddenly felt curious about the Other. He explained that "it was interesting just that kind of cultural curiosity that probably anybody would feel anytime they get to communicate with somebody who would have some sort of different experience from themselves." The curiosity aroused in him made him realize that "the communication style is so different for people in different countries." He found it difficult to describe the differences in communication because they were not only due to his communication partners not having English as their mother tongue. Thinking about it further, he formulated some more concrete reasons. He attempted to characterize the communicative behaviour of people in his country based on a comparison with other countries. Two points stood out: Firstly, "in the United States we tend to be really assertive, but at the same time usually really friendly," and secondly, "Americans, in general, tend to respond like they're right without question, which is maybe not the best quality to have." For the 21-year-old, the Own gains sharper contours thanks to the encounter with the Other, a point which he himself made as well: "You start to notice your own when you're communicating with somebody who has different ones." The gaze of the Own initiated by the communicative setting out for the Other is a critical gaze. And we do not know where that leads.

Whereas the 21-year-old's reflections are aimed at the Own which had become visible in his confrontation with the Other, for the 24-year-old American globetrotter it is the setting out itself which she examines carefully and critically. She reflects both on the social costs her setting out has caused in terms of reduced contact with her siblings and on the risk of 
fragmented experiences. The latter emerges implicitly from her narrative when she describes how she uses her photos to attempt to link up different experiences in different countries. This also indicates that she had found a strategy to deal with the risks she had acknowledged in a constructive manner. For her, digital media are an important tool with which to maintain links across national borders. She never switches off her computer so that she can always be contacted, even in the middle of the night, especially by her best friend in America, who could never work out the time difference. She recalled: "So I leave it [the computer] open and she'd call me like four in the morning. But then I can hear it and I would answer." She also wants to be available for her parents. In addition, being permanently online, she could read the online edition of the local newspaper in the place she came from. She admitted that being online gave her the feeling of being close: "I feel connected," she said. Alongside the relationships with people from her home country, she described how she used Facebook to maintain friendships which had arisen on the move.

The Turkish student also uses digital media, as mentioned earlier, as the place and instrument for maintaining relationships. For different types of relationships he makes use of different digital services. He uses Skype to stay in regular contact with his family whereas the social network Netlog (2010) is for initiating new relationships and Facebook for communicating with friends. On top of that, like the 24-year-old American, he stays in touch with what is going on in his home country by regularly reading the online edition of a Turkish newspaper.

The 21-year-old American student addresses his university's online project "Global Modules" as one possibility for global communication. He commented on his visualization in answer to the question "Who am I on Global Modules?” as follows:

I'm putting in the centre of it a picture of the world. ... There are a bunch of small wavery lines from my face down onto the globe up in the centre. These will be my little ideas that I'm sending off into the world wide web. Then I'll do the same for these other little faces.

The 21-year-old uses his drawing to emphasize the swapping of ideas, which have not only brought him closer to the Foreign but also to the Own (Fig. 4.6). He also appreciates the limitations of digitally assisted communication in comparison with communication face to face, such as the loss of facial expressions and vocal inflections. 


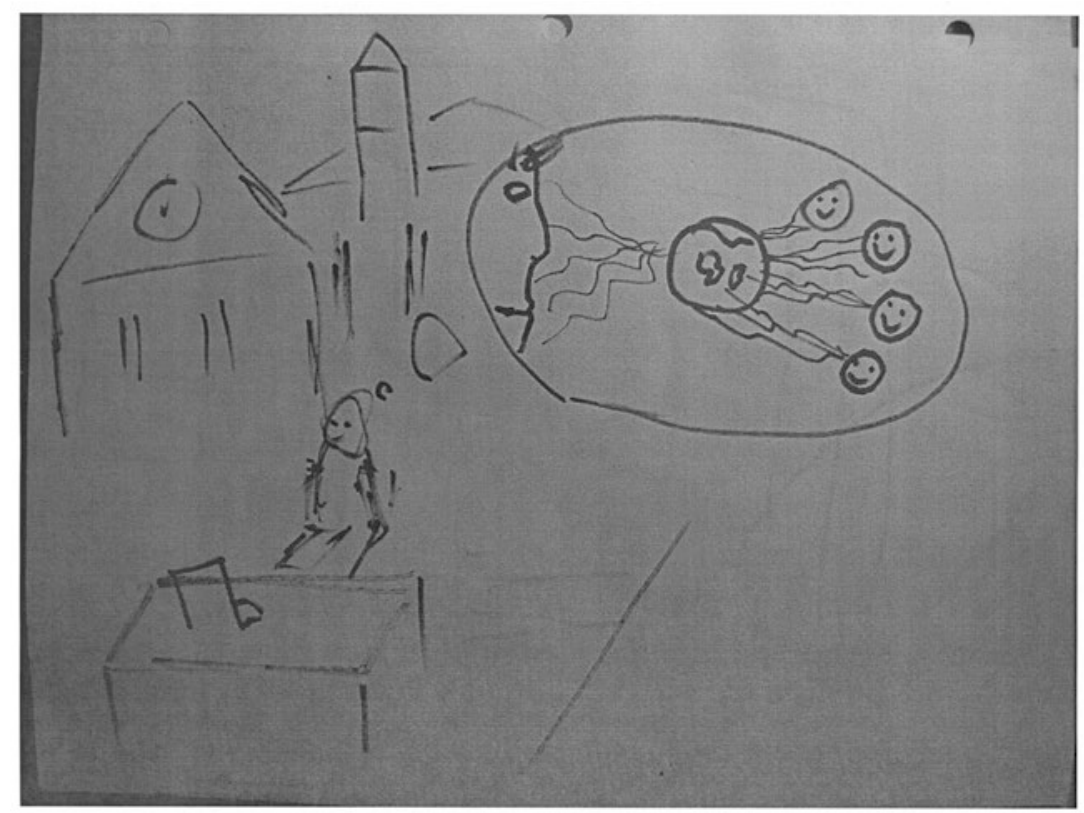

Fig. 4.6 Digitally assisted global communication (network actor, m, 21, USA)

The stories described here represent notions of setting out into other sociocultural territories. The contacts with other cultures and societies are partially based on the physical crossing of borders and partly on virtual border crossings. The double-faced nature of the experience as joyful expectation on the one hand and worries about possible disappointments and losses on the other comes across most clearly when the journey is geographical in nature. In these circumstances, the focus on maintaining and entering into social relationships is even stronger. Whereas his current circle of friends is still a haven of safety for the 21-year-old, the communication patterns of the people he is communicating with from other countries have become a challenge to take critical stock of his own style of communication. 


\subsubsection{Setting Out and Breaking Away as a Political Project}

The narrations about setting out and breaking away are political in nature to the extent that they criticize the ruling sociocultural system and convey visions of an alternative future as well. The stories were told by four female network actors and bloggers aged 21 to 26 from the Arab world. None of the Western network actors or bloggers told stories of this type. These narrations criticize a lack of freedom of speech and opinion, the discrimination of minorities, and the way in which nature and the environment are treated in the region. At the same time the narrations include alternative visions and wishes like freedom of speech, giving minorities a voice, dealing responsibly with the environment and resources, and contacts with Western countries, also to show that the narrators' countries have other sides to them than the official ones relayed by the media, which are controlled by the ruling powers. In contrast to the biographically motivated stories, here the motivation to break away prevails. The narrations date back to the time before, during, or shortly after the Arab Revolution ${ }^{22}$ in 2010 and 2011.

It was in 2006 that she began to take a critical look at the political conditions in her country and founded the digital platform Mideast Youth (n.d.), ${ }^{23}$ recalled a 24 -year-old network actor. Taboo topics and anxietyprovoking topics were given a forum on this platform, as the 24-year-old explained: "We talk a lot about taboos, you know, homosexuality, like I said, atheism ... sex traffic, things that people don't talk about because they are scared." This platform was also the launching pad for campaigns like the "March 18 Movement," which championed the freedom of speech for bloggers. Before the Arab Revolution, a 23-year-old network actor got involved in an environmental initiative which addresses issues concerning energy consumption and waste disposal. ${ }^{24}$ This initiative was addressed to

${ }^{22}$ The Arab narrators always called the political protests in the Middle East and North Africa in 2010/2011 a revolution whereas in the Western world the name "Arab Spring" dominates.

${ }^{23}$ Mideast Youth (n.d.) is a platform for network actors which was founded in Bahrain in 2006. Its aim is to initiate critical exchange on the political situation in the Middle East between network actors who live in the region and those from other parts of the world. As the platform has since started to include political issues and problems from other parts of the world, it has been renamed Majal: Amplifying Underrepresented Voices (n.d.).

${ }^{24}$ The involvement of the 23-year-old network actor from Saudi Arabia can be ascribed to "Islamic Environmentalism," which was proposed in the 1960s by the Iranian-American philosopher Seyyed Hossein Nasr. Eco-Muslims advocate the economical use of resources, 
the population as a whole and not only to the government. Two network actors saw the Arab Revolution as a challenge to turn their blogs into political blogs. One of them subsequently joined the "March 18 Movement"; she said that she also blogged about women's rights, and her involvement developed in parallel with the political events. When a man was killed by the police in Egypt because he had filmed the police in action, her tweets had rocketed. When faced with similar events, she tried to make the topic trend on Twitter. A 26-year-old Yemeni journalist had been using all internet services since the beginning of the Revolution; she reported being online for six hours a day. As she put it, "I tweet, I blog, I skype, I sms." Her full attention was focused on politics in Yemen and the Middle East. She had become an important source of information for the international media. The 26-year-old described herself as follows: "I talk freely about my political views, which are like one of the taboos in the Arab countries."

The motivations and goals behind the notion of setting out and breaking away are very clearly formulated in the narrations of the Arab network actors. Sometimes they are specific and sometimes general; sometimes they are addressed to inhabitants of their own country or region and sometimes to a wider public beyond the Middle East and North Africa. The 23-year-old environmental activist from Saudi Arabia justified her involvement with her love for nature and her observations that nobody in her country was doing anything about environmental issues. Together with Others, she wanted to create an awareness of "the importance of litter and recycling." The 24-year-old network actor from Bahrain who was actively engaged in increasing respect for human rights in the region could also give very precise reasons for her activities: "There was a lack of freedom of speech in the Middle East." Above and beyond that she wanted Mideast Youth (n.d.), the online platform she had founded, to give discriminated minorities in the region a voice. She reported:

animal welfare, healthy nutrition, and sustainable pilgrimages, citing the Quran to justify their involvement. According to this interpretation of the Quran, the world consists of signs of God, which should be protected. Most organizations associated with Eco-Islam are based in the Western world; according to the 23-year-old network actor, as a result of the Arab Revolution, many ecological groups and organizations were founded in the Middle East and in North Africa. Social networks, blogs, and websites play an important role in disseminating Eco-Islam.

The information about Eco-Islam presented here comes from an interview with Monika Zbidi (2014). In her dissertation, Zbidi analysed Eco-Islam as a modern Islamic movement. 
I like to discuss about ethnic and religious minorities. ... We started talking about Bahá'ís and then atheism and then gay rights; so we started inviting gay people to come in, gay or bisexual or transgender people to give interviews with Mideast Youth.

The 24-year-old is convinced that "without their human rights no one else can have human rights." A 21 -year-old network actor from the United Arab Emirates wants to help her own generation to find their own voice: "We wanted people to know 'look, we're the youth in the Middle East and we are active online, we are active socially and we believe in causes'. We have the voice and we wanted to be heard."

Feelings are rarely addressed directly in the narrations of the Arab network actors; only one of them reckoned that she would reveal online that she was happy, but not that she was sad or annoyed. Implicitly, however, the narrations indicate a broad spectrum of feelings which accompany the setting out and breaking away, such as anger, rage, fear, worry, hope, longings, and disappointment.

Alongside their motivations, reflections also take up much space in the narrations of the Arab network actors. It is difficult to differentiate clearly between motivations and reflections, but reflections have a greater thematic range. They relate to the social status quo, the attempts being made at the time of the narrative to bring about change, the narrators' own role and own actions in this process, and the perceived boundaries.

When characterizing the social status quo, some of the Arab network actors emphasized the taboos which they should not mention from the viewpoint of the ruling powers while some of them focused on the lack of human rights. "Usually in the Arab countries they have three taboos that they don't talk about: It's politics and religion and sex," reported a 25-year-old Yemeni network actor. Another network actor, this time from Bahrain, challenged the existence of social taboos and the lack of human rights:

How can we learn about other religions if we are not meant to talk about them? How can you believe about other human beings and about the value of life and the value of human rights if you have no rights?

The political protests which took place in several Arab countries in 2011 are interpreted by a 21 -year-old network actor as follows: "It's like a political awakening what's happening in the country. Already the 
revolution had made the people realize their own identity, their own nationality, their own political rights, and people now are fighting for their democracy." The word "awakening" refers to the somnolent state which citizens were in before it was overcome because something was recognized as being important enough to fight for, which is one interpretation of the quote. One of the network actors wanted to support this awakening by breaking the taboos on her blog: "When I'm blogging I'm trying to break that wall and talk about one of those taboos. And even when I talk about gender issues I'm also trying to talk about sex ... to shock the people with my opinion." She wants to "shock" not only her own country but also the global public, by providing insights into a different side of Yemen which had previously been invisible:

We have a lot of stories, a lot of issues, a lot of aspects, a lot of faces, that we want the world to know about. And it will be shocking for the rest of the world to know that there is another side of Yemen except the terrorism side. And so I would like to be part of that shock.

Whether making what she considers concealed aspects of her country visible really is a shock for the global public remains to be seen. What is crucial, however, is her intention to debunk the myths, to make things public, and to break the silence, in short to risk a communicative rebellion. But such subversive acts also have their limits for the blogger. She would never write about religion because that would be life threatening. Recognizing the limits and factoring them into the calculation are concerns which affect all of the network actors quoted in this section in order to protect themselves and their families. One of them muses that this is so "because you don't know ... who is monitoring you." That means that she never lets slip online where she lives, who her parents are, or when she leaves the house.

The stories about breaking away told by the Arab network actors not only unfold in digital space, although they believe it plays a central role. They tend to use several digital communication and information channels, as one of the network actors revealed: "When I open my laptop it's my Facebook open, my Twitter, my blog, BBC Yemen - it's just everything. I don't know how I'm able to do that but I do it." "Social media is a helping tool," explained the same network actor, adding shortly afterwards that "[s]ocial media is the future." What makes the online networks so attractive to these users? They appreciate the potential of digital media for 
staying connected, in the words of one network actor: "I love Facebook because I can keep in touch with everybody." Another one added: "I think the online world makes the whole world smaller." They also welcome the speed of communication and the medium's potential for distributing news, as this network actor noted: "It's usually something about spreading my passion around." Finally, digital space is portrayed as a safe space: "I think some of the things we do, we cannot do outside of Mideast Youth; things that are homosexual, human rights, discussions about atheism. This for sure you cannot talk about in public without being arrested or in danger." One network actor called the platform a place where they could learn how to discuss such topics and to challenge everything they had been taught. That is why the platform was also a place of learning, or as the network actor put it, "Mideast Youth is education." It is a place which encourages an open discussion and the dissemination of ideas. Being connected with like-minded people is, not surprisingly, also a suitable instrument of combat, as referred to in the following statement: "We use new media in order to fight against oppression-oppression against ourselves, oppression against minorities." Equally unsurprisingly, given the qualities outlined earlier which support the setting out and breaking away of the network actors, some of them describe themselves as being addicted to digital media. Islam and the internet are no contradiction, in the words of a 23-year-old: "I'm Moslem, I mentioned that I'm in [name of town], that I'm an environmentalist, but I love the internet and I used to be an internet junkie." This love for the internet does not appear to be due to the political merits of the medium alone but to its virtues for communication in general, as was much more clearly expressed at a different point in the interview, when the network actor described how easy it was to find people on Facebook whom she had met somewhere. The internet opens up different contents, intentions, and activities. It is also conceivable that the political use of the internet, which currently dominates for the network actors, will give way to a more private use again at a later stage and in a different political situation.

The network actors' political criticism and comments are, obviously, addressed to an audience. Reactions-desirable and undesirable-are never long in coming. The undesirable reactions include threatening emails, like the message quoted by one network actor: "Wake up young lady, you gotta stop criticizing the president otherwise your mother and sister will be deprived of you[r] recklessness." The same network actor recalled an armed attack on a political activist and journalist in her own 
home and talked about other journalists who had been beaten up on the street. Those threats were more than compensated for by the words of approval she received from readers of her blog "and from people who believe in me more than I believe in myself." Another network actor explained that she had become more courageous thanks to the support of her readers and dared to say more: "So when you have more supporters on your side it becomes easier to be more outspoken because you have more people who can back you up." Although this support was important, she did not expect only words of approval. Different opinions, with the exception of threatening emails, were welcome on the platform in the same way as the coexistence of diversity was an important component of the concept behind the platform.

As mentioned at the beginning of this section, the narrations about breaking away were recounted by the Arab network actors when the political protests in the individual countries in the Middle East and North Africa were well under way or had just come to an end. Not only the current events but also the happenings leading up to them were very much in the narrators' minds and were described by one narrator as follows: "We're talking about many years of suffering, of people suffering in their own nation by their own regime." The narrations are also to be seen in the context of specific life stories, which have fostered specific outlooks on life, a critical gaze, or a cosmopolitan attitude. The network actor who is actively engaged in human rights sees the roots for this commitment in her childhood. Even then it was clear to her that "I never wanted an office job, I never wanted to work from 9 to 5, I always wanted to work for myself and I wanted to do something that will change everyone's life." Another one did a degree in International Relations, which must have promoted her interest in the transregional exchange of opinion which is so important to her, as the following statement reveals: "I love the fact that you can share ideas with the community both at a regional local level and also at a very international level as well." A third network actor described her training as a journalist as an "eye-opening career," justifying it by saying "I got to know to be in contact with real issues or serious issues that Yemen has to face." Not one of four network actors became the author of her story about setting out and breaking away by chance; their own ambitions interacted with the historical situation which appealed to those very ambitions. 


\section{REFERENCES}

Bönsch-Kauke, M. (2005). Ohne Spaß macht's keine Spaß! Zur Entwicklung des Humor-Verstehens im Sozialisationsprozess [Without fun, it's no fun! Developing an understanding of humour in the socialization process]. Medien + Erziehung, 49(4), 16-20.

Grimm, J., \& Grimm, W. (1984). Deutsches Wörterbuch [German dictionary] (Vol. 1). Leipzig: S. Hirzel Deutscher Taschenbuchverlag. (Original work published 1854).

Majal: Amplifying underrepresented voices. (n.d.). Retrieved from https:// majal.org/

Mideast youth. (n.d.). Retrieved from https://mideastyouth.com/

Netlog. (2010). Retrieved from http://de.netlog.com

Schachtner, C., \& Duller, N. (2014). Kommunikationsort Internet: Digitale Praktiken und Subjektwerdung [The internet as a place of communication: Digital practices and subjectification]. In T. Carstensen, C. Schachtner, H. Schelhowe, \& R. Beer (Eds.), Digitale Subjekte (pp. 81-154). Bielefeld: transcript.

Scudder, G., Jr. (2008). Global Modules: Die Nutzung des Internets zum Aufbau interkultureller Communities [Global modules: Using the internet to develop intercultural communities]. In C. Schachtner \& A. Höber (Eds.), Learning communities: Das Internet als neuer Lern- und Wissensraum (pp. 109-120). Frankfurt am Main: Campus.

Seel, M. (2001). Inszenieren als Erscheinenlassen: Thesen über die Reichweite eines Begriffs [Staging made visible: Propositions on the scope of a term]. In J. Früchtl \& J. Zimmermann (Eds.), Ästhetik der Inszenierung (pp. 48-62). Frankfurt am Main: Suhrkamp.

SWR Kindernetz. (2020). Retrieved from www.kindernetz.de

Wikipedia. (2020). Gossip girl. Retrieved from https://en.wikipedia.org/wiki/ Gossip_Girl

Zbidi, M. (2014). Islamisch motivierter Umweltschutz [Islamic environmentalism]. In Mediendienst integration. Retrieved from http://mediendienst-integration.de/artikel/umweltschutz-oeko-muslime.html. 
Open Access This chapter is licensed under the terms of the Creative Commons Attribution 4.0 International License (http://creativecommons.org/licenses/ by $/ 4.0 /$ ), which permits use, sharing, adaptation, distribution and reproduction in any medium or format, as long as you give appropriate credit to the original author(s) and the source, provide a link to the Creative Commons licence and indicate if changes were made.

The images or other third party material in this chapter are included in the chapter's Creative Commons licence, unless indicated otherwise in a credit line to the material. If material is not included in the chapter's Creative Commons licence and your intended use is not permitted by statutory regulation or exceeds the permitted use, you will need to obtain permission directly from the copyright holder. 